\title{
Comprehensive modelling study on observed new particle formation at the SORPES station in Nanjing, China
}

\author{
Xin Huang ${ }^{1,2}$, Luxi Zhou ${ }^{3,4}$, Aijun Ding ${ }^{1,2}$, Ximeng Qi ${ }^{1,2}$, Wei Nie ${ }^{1,2}$, Minghuai Wang ${ }^{1,2}$, Xuguang Chi ${ }^{1,2}$, \\ Tuukka Petäjä $^{3}$, Veli-Matti Kerminen ${ }^{3}$, Pontus Roldin ${ }^{3}$, Anton Rusanen ${ }^{3}$, Markku Kulmala ${ }^{3}$, and Michael Boy ${ }^{3}$ \\ ${ }^{1}$ Joint International Research Laboratory of Atmospheric and Earth System Sciences and School of Atmospheric Sciences, \\ Nanjing University, Nanjing, 210023, China \\ ${ }^{2}$ Collaborative Innovation Center of Climate Change, Nanjing, Jiangsu Province, China \\ ${ }^{3}$ Department of Physics, University of Helsinki, P.O. Box 64, 00014 University of Helsinki, Helsinki, Finland \\ ${ }^{4}$ Helsinki University Centre for Environment, P.O. Box 65, 00014 University of Helsinki, Helsinki, Finland
}

Correspondence to: Aijun Ding (dingaj@nju.edu.cn)

Received: 22 July 2015 - Published in Atmos. Chem. Phys. Discuss.: 13 October 2015

Revised: 2 February 2016 - Accepted: 2 February 2016 - Published: 1 March 2016

\begin{abstract}
New particle formation (NPF) has been investigated intensively during the last 2 decades because of its influence on aerosol population and the possible contribution to cloud condensation nuclei. However, intensive measurements and modelling activities on this topic in urban metropolitan areas in China with frequent high-pollution episodes are still very limited. This study provides results from a comprehensive modelling study on the occurrence of NPF events in the western part of the Yangtze River Delta (YRD) region, China. The comprehensive modelling system, which combines the WRF-Chem (the Weather Research and Forecasting model coupled with Chemistry) regional chemical transport model and the MALTE-BOX sectional box model (the model to predict new aerosol formation in the lower troposphere), was shown to be capable of simulating atmospheric nucleation and subsequent growth. Here we present a detailed discussion of three typical NPF days, during which the measured air masses were notably influenced by either anthropogenic activities, biogenic emissions, or mixed ocean and continental sources. Overall, simulated NPF events were generally in good agreement with the corresponding measurements, enabling us to get further insights into NPF processes in the YRD region. Based on the simulations, we conclude that biogenic organic compounds, particularly monoterpenes, play an essential role in the initial condensational growth of newly formed clusters through their low-volatility oxidation products. Although some uncertain-
\end{abstract}

ties remain in this modelling system, this method provides a possibility to better understand particle formation and growth processes.

\section{Introduction}

Ambient aerosols affect human health adversely, degrade visibility, and play an important role in climate change through directly scattering/absorbing solar radiation or indirectly modifying microphysical properties of clouds (EidelsDubovoi, 2002; Davidson et al., 2005; Lohmann and Feichter, 2005; Myhre et al., 2013). Atmospheric new particle formation (NPF), characterized by a sharp increase in number concentration of nucleation-mode aerosol, has been observed under a wide variety of circumstances and has been shown as a significant source of atmospheric fine particles (O'Dowd et al., 2002; Kulmala and Kerminen, 2008; Gao et al., 2011; Guo et al., 2012; Guo et al., 2014; Wang et al., 2014). As the newly formed particles and their following growth may lead several-fold increases in aerosol number concentrations, atmospheric NPF could substantially contribute to the global CCN (cloud condensation nuclei) budget and its subsequent cooling effect (Lihavainen et al., 2003; Merikanto et al., 2009; Yu and Luo, 2009; Wang and Penner, 2009; Kerminen et al., 2012; Makkonen et al., 2012; Scott et al., 2014). 
NPF has been extensively and intensively studied globally during the last 2 decades. It is well known that particle formation in the atmosphere is strongly dependent on the abundance of sulfuric acid (Weber et al., 1999; Kulmala et al., 2004b; Sipila et al., 2010). Meanwhile, other compounds in the atmosphere may be responsible for NPF occurrence in different environments. Iodine-containing vapours were identified as the precursors for marine NPF (O'Dowd et al., 2002). Observations in Pittsburgh imply that ammonia could considerably enhance the atmospheric particle formation (Q. Zhang et al., 2004). In the boreal forest, oxidation products of monoterpenes together with sulfuric acid were very likely to lead to NPF (Schobesberger et al., 2013) and new findings indicate that organic amines (e.g. dimethylamine) can enhance water-sulfuric acid particle formation rates more than 1000-fold compared to ammonia (Almeida et al., 2013). In addition to direct in situ observations of NPF events, model simulation has been serving as a useful tool for analysing NPF dynamics since the 1990s (Kulmala et al., 1995; Kerminen and Wexler, 1996; Korhonen et al., 1999). In recent years, the MALTE model has been successfully utilized in NPF analysis - for instance, reproducing $\mathrm{OH}$ radical and gaseous sulfuric acid levels (Petäjä et al., 2009), validating various plausible nucleation mechanisms and particle growth (Boy et al., 2007; Wang et al., 2013b), and identifying important factors influencing NPF occurrence (Boy et al., 2006, 2008a; Ortega et al., 2012).

As one of the most economically invigorating and densely populated countries, China features simultaneous high aerosol loadings and NPF rates (S. Liu et al., 2008; Gao et al., 2011; Guo et al., 2012; Qi et al., 2015). Moreover, the condensational growth of nucleation-mode particles has been indicated as a plausible cause of regional haze events (Guo et al., 2014). Since the 2000s, several field campaigns as well as long-term measurements have been conducted in several regions such as Beijing, the Pearl River Delta as well as the Yangtze River Delta, showing high occurrence frequencies and formation rates across China (S. Liu et al., 2008; Gao et al., 2009; Yue et al., 2010; Herrmann et al., 2014; Qi et al., 2015; Xiao et al., 2015). However, modelling studies that provide a further insight into the processes of atmospheric aerosol formation, are still very limited in China. Numerical simulations of formation and growth processes usually require detailed and high time-resolving measurements of the relevant compounds - however, hardly any field campaign or in situ measurement station in China meets this requirement. The novel combination of a regional chemical transport model and a zero-dimensional box model with detailed aerosol dynamics makes it possible to accomplish NPF modelling studies without direct measurements of all specific chemical species. Here, we present a comprehensive modelling study targeted at reproducing observed NPF events under distinct conditions at the Station for Observing Regional Processes of the Earth System (SORPES) at Nanjing University in Nanjing, China (Ding et al., 2013a). This is the first

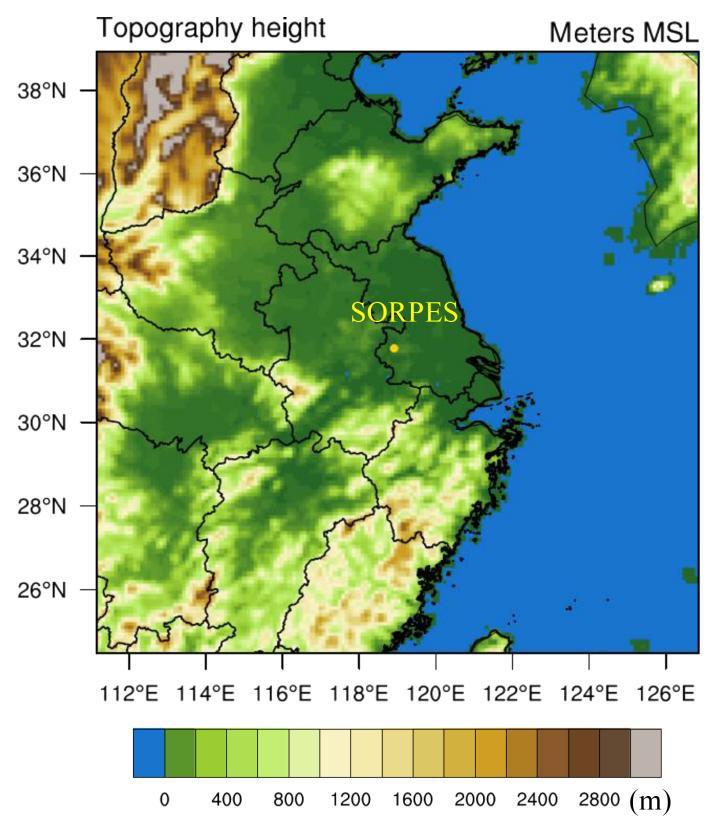

Figure 1. WRF-Chem model domain and topographic field (in metres). The yellow dot marks the location of the SORPES station.

attempt to integrate the regional model, box model and in situ measurements to investigate NPF events in China, enabling us to gain more insights into NPF mechanism in the YRD region.

\section{Data and methodology}

\subsection{In situ measurements}

The SORPES site is located in the Xianlin campus of Nanjing University in the suburban area northeast of Nanjing, which is about $20 \mathrm{~km}$ east from the downtown area $\left(118^{\circ} 57^{\prime} 10^{\prime \prime} \mathrm{E}\right.$, $32^{\circ} 7^{\prime} 14^{\prime \prime} \mathrm{N}, 40 \mathrm{~m}$ a.s.l. as shown in Fig. 1 in Ding et al., 2013a). This site, with few local emission sources around it, is generally upwind of downtown Nanjing and also downwind of the city clusters of the YRD region. Hence it can be regarded as a regional background station (Ding et al., 2013a).

On-line and high time-resolving measurements of trace gases, aerosol characteristics, and relevant meteorological parameters have been conducted since the summer of 2011. Ozone $\left(\mathrm{O}_{3}\right)$, sulfur dioxide $\left(\mathrm{SO}_{2}\right)$, nitrogen monoxide (NO), nitrogen dioxide $\left(\mathrm{NO}_{2}\right)$, total reactive nitrogen $\left(\mathrm{NO}_{y}\right)$, carbon monoxide $(\mathrm{CO})$ and $\mathrm{PM}_{2.5}$ (fine particulates less than 2.5 microns in aerodynamic diameter) are routinely measured by Thermo Instruments (TEI 49i, 43i, 42i, 42iY and 48i) and MARGA (Monitor for Aerosols and Gases in Ambient Air) (Ding et al., 2013a, b). The Differential Mobility Particle Sizer (DMPS) coupling a differential mobility analyser with two different flow rates and a condensation particle 
Table 1. Chemical species from WRF-Chem input to MALTEBOX.

\begin{tabular}{ll}
\hline WRF-Chem & MALTE-BOX \\
\hline Acetaldehyde (CCHO) & $\mathrm{CH}_{3} \mathrm{CHO}$ \\
Acetone (ACET) & $\mathrm{CH}_{3} \mathrm{COCH}$ \\
Methanol (MEOH) & $\mathrm{CH}_{3} \mathrm{OH}$ \\
Methyl Vinyl Ketone (MVK) & $\mathrm{MVK}$ \\
Isoprene (ISOPRENE) & $\mathrm{C}_{5} \mathrm{H}_{8}$ \\
Terpenes (TERP) & alpha-pinene \\
& beta-pinene \\
& camphene \\
& myrcene \\
& carene \\
& limonene \\
\hline
\end{tabular}

counter are used to measure number distributions of atmospheric particles from 6 to $800 \mathrm{~nm}$ (Herrmann et al., 2014; Qi et al., 2015). More thorough information on the instruments at the SORPES site is elaborated in detail in Ding et al. (2013a, b).

\subsection{Model description}

\subsubsection{MALTE-BOX model}

MALTE is a one-dimensional model comprised of boundary layer meteorology, biogenic emission of volatile organic compounds, gas-phase chemistry and aerosol dynamics in order to predict particle formation and growth processes under atmospheric conditions (Boy et al., 2006). Here, we apply the zero-dimensional version, namely the MALTE-BOX model, to simulate NPF events at the SORPES station. In the MALTE-BOX model, boundary layer meteorology and biogenic emission modules are switched off; instead, the biogenic and anthropogenic VOC emissions and their following transport and dispersion are calculated by the regional chemical transport model WRF-Chem. Concentration of various organic compounds at the SORPES station predicted by WRF-Chem model are input into MALTE-BOX model every 10 min (Table 1 provides the compounds calculated by WRF-Chem as input to MALTE-BOX). Likewise, measured concentrations of trace gases including $\mathrm{CO}, \mathrm{SO}_{2}, \mathrm{NO}, \mathrm{NO}_{2}$ and $\mathrm{O}_{3}$, with the same temporal resolution, are also included as input fields. In addition to gas phase precursors, the inputs also include an initial particle number size distribution at 00:00 LT on each day, ambient temperature, relative humidity and the condensation sink of sulfuric acid (as defined in Sect. 2.3).

In the MALTE-BOX model, particles are assumed to be spherical. A fixed sectional approach with 40 size bins ranging from 1.4 to $2000 \mathrm{~nm}$ in diameter is used in the present study. The aerosol dynamics has all basic aerosol processes, including nucleation, condensation, coagulation and deposition. The new particle formation rates of newly formed clus- ters are estimated by the kinetic nucleation theory of sulfuric acid (Sihto et al., 2006), which is related to the sulfuric acid concentration as follows:

$J=k_{1} \times\left[\mathrm{H}_{2} \mathrm{SO}_{4}\right]^{2}$,

where $k_{1}$ is the kinetic coefficient that includes both the collision frequency and the probability of forming a stable cluster after the collision. Kinetic nucleation theory has been shown to have good performance in simulating cluster formation in various environments including both clean continental area and polluted urban site (Wang et al., 2013b; Zhou et al., 2014). The nucleated particles were added to the first size bin in the model.

We conducted a set of sensitivity simulations to establish a suitable value for the nucleation coefficient $k_{1}$. After comparing the simulations and DMPS measurements, $k_{1}$ was set to $6.0 \times 10^{-13} \mathrm{~cm}^{3} / \#$ for 10 July and 22 August, and $2.2 \times 10^{-10} \mathrm{~cm}^{3} / \#$ for 22 June. These values were similar to those we commonly used in the simulations for NPF at other stations (Boy et al., 2008a; Paasonen et al., 2010; Zhou et al., 2015). The high value on 22 June might imply that other low-volatility vapours - most probably from anthropogenic origin - are involved and play a crucial role in the particle formation process at this site. Moreover, being limited by the detectable size of the DMPS (we can monitor particles larger than $6 \mathrm{~nm}$ in diameter), means that the observed formation process could be steered by the condensational growth of the smallest clusters to the detection limit.

We included relevant chemical reactions of the MCM (Master Chemical Mechanism) in this model, as described in Boy et al. (2013). The chemistry scheme included the full MCM chemical paths for the following parent molecules: methane, methanol, formaldehyde, acetone, acetaldehyde, 2-methyl-3-buten-2-ol (MBO), isoprene, alpha-pinene, beta-pinene, limonene and beta-caryophyllene. The Kinetic PreProcessor (KPP) was applied to numerical solving for the concentrations of each individual compound (Damian et al., 2002), except for those species whose concentrations were manually input from direct measurements and the WRF-Chem model. Apart from sulfuric acid, about 20 low-volatility organic compounds (ELVOCs) and seven selected semi-volatile organic compounds (SVOCs) are regarded as condensing vapours, following the simplified chemical mechanism presented by Ehn et al. (2014). Specifically, seven representative SVOCs (MCM-nomenclature: C719OOH, LIMALOOH, C924OOH, NORLIMOOH, C8110OH, C818OOH and $\mathrm{C} 81900 \mathrm{H})$ with vapour pressures estimated to range from $10^{4}$ to $10^{6}$ molecules $\mathrm{cm}^{-3}$ (using the group contribution method described by Nannoolal et al., 2008) and recently detected ELVOCs $\left(\mathrm{C}_{10} \mathrm{O}_{5-12} \mathrm{H}_{x}, \mathrm{C}_{10} \mathrm{NO}_{5-13} \mathrm{H}_{x}\right.$ and $\left.\mathrm{C}_{20} \mathrm{O}_{8-16} \mathrm{H}_{x}\right)$ with vapour pressures between 10 and $10^{3}$ molecules $\mathrm{cm}^{-3}$ are included as condensing vapours in the model. 


\subsubsection{WRF-Chem}

The WRF-Chem version 3.6 was used here to estimate concentrations of various organic vapours from anthropogenic and biogenic emissions as there was no VOC measurement at the SORPES site during the study period. WRF-Chem is an online three-dimensional, Eulerian chemical transport model that considers the complex physical and chemical processes, such as emission and deposition of pollutants, advection and diffusion, gaseous and aqueous chemical transformation, aerosol chemistry and dynamics (Grell et al., 2005). It is capable of simulating atmospheric chemistry on a regional scale and has been successfully applied in several of our previous studies (Huang et al., 2014, 2015). In this study, the model domain covered East China and its surrounding area, centred at $32.0^{\circ} \mathrm{N}, 119.0^{\circ} \mathrm{E}$ with a $20 \times 20 \mathrm{~km}$ grid resolution, as demonstrated in Fig. 1. There are 24 vertical layers from the ground level to the top pressure of $50 \mathrm{hPa}$, in which 10 layers are placed under $1 \mathrm{~km}$ to better resolve the boundary layer processes. The 6-hourly final operational global analysis (FNL) data with a $1^{\circ} \times 1^{\circ}$ spatial resolution produced by the National Centres for Environmental Prediction (NCEP) was used as initial and boundary conditions of meteorological fields. The simulations were conducted for June to August 2013 when NPF events were frequently detected (Qi et al., 2015). During the simulation period, each run covered $60 \mathrm{~h}$, in which the first $12 \mathrm{~h}$ were just for model spin-up and the last $48 \mathrm{~h}$ results were adopted for following analysis and box modelling. The outputs of compound concentrations from the preceding run were treated as the initial conditions for the next run. Key physical parameterization options for the WRF-Chem modelling are the Noah land surface scheme to describe the land-atmosphere interactions (Ek et al., 2003), the Lin microphysics scheme (Lin et al., 1983) with the Grell cumulus parametrization to reproduce the cloud and precipitation processes (Grell and Devenyi, 2002), the YSU boundary layer scheme (Hong, 2010), and the RRTMG short- and long-wave radiation scheme (Mlawer et al., 1997).

Anthropogenic emissions from power plants, residential combustion, industrial processes, on-road mobile sources and agricultural activities were derived from the MEIC database (Multi-resolution Emission Inventory for China, see www.meicmodel.org). Emissions of major pollutants, such as carbon monoxide, sulfur dioxide, nitrogen oxides, ammonia and speciated VOCs are all included in this emission inventory database. The MEGAN (Model of Emissions of Gases and Aerosols from Nature, version 2) module embedded in WRF-Chem is used to calculate biogenic emissions online (Guenther et al., 2006). It estimates the net emission rates of isoprene, monoterpene and other biogenic VOCs from terrestrial ecosystems into the above-canopy atmosphere. Gas-phase chemistry is explicitly represented by the model through the SAPRC photochemistry scheme (Carter, 1999), which includes 225 gas-phase reactions among 81 chemical species in the model. We mapped some predicted organic species in WRF-Chem to the MALTE-BOX following the correspondence denoted in Table 1. Regarding the monoterpenes (alpha-pinene, beta-pinene, camphene, myrcene, carene and limonene) used in MALTE-BOX chemistry (details in Boy et al., 2013), the distribution was performed equally because no VOC-measurement were available at the SORPES station during the study period.

\subsection{Data analysis}

The calculations of particle growth and formation rates are conducted following the procedures outlined by Kulmala et al. (2012). The formation rate is obtained from the following equation:

$J_{\mathrm{dp}}=\frac{\mathrm{d} N_{\mathrm{dp}}}{\mathrm{d} t}+\operatorname{Coag} S_{\mathrm{dp}} \times N_{\mathrm{dp}}+\frac{\mathrm{GR}}{\Delta \mathrm{dp}} \times N_{\mathrm{dp}}+S_{\text {losses }}$,

where $J_{\mathrm{dp}}$ refers to the particle formation rate of diameter dp and the first term on the right-hand side is the time evolution of the particle number concentration with size ranging from $\mathrm{dp}$ to $\mathrm{dp}+\Delta \mathrm{dp}$. The second term derives the coagulation loss by the product of coagulation sink $\left(\mathrm{Coag} \mathrm{S}_{\mathrm{dp}}\right)$ and the number concentration in the size range [dp, dp $+\Delta d p]$. The third term is the growth out of the considered size range, in which GR means measured growth rate. The last term $S_{\text {losses }}$ represents additional losses, which were not considered in this study.

The growth rate of particles during the NPF events can be expressed as

$\mathrm{GR}_{\mathrm{dp}}=\frac{d_{\mathrm{p} 1}-d_{\mathrm{p} 2}}{t_{1}-t_{2}}$,

where $d_{\mathrm{p} 1}$ and $d_{\mathrm{p} 2}$ are the representative of the diameter of nucleated particles at the times $t_{1}$ and $t_{2}$, respectively. For calculation, $d_{\mathrm{p} 1}$ and $d_{\mathrm{p} 2}$ is then defined as the central size of each bin and $t_{1}$ and $t_{2}$ are the moments when the concentration of this size bin peaks.

The condensation sink determines how rapidly condensable vapour molecules will condense onto pre-existing aerosols. It can be derived by DMPS-measured particle number size distribution according to the following method (Kulmala et al., 2001):

$\mathrm{CS}=4 \pi D \sum_{\mathrm{dp}^{\prime}} \beta_{\mathrm{m}, \mathrm{dp}^{\prime}} \mathrm{dp}^{\prime} N_{\mathrm{dp}^{\prime}}$,

where $D$ is the diffusion coefficient of the condensing vapour, $\beta_{\mathrm{m}}$ is a transition-regime correction, $\mathrm{dp}^{\prime}$ is the discrete diameter and $N_{\mathrm{dp}^{\prime}}$ is the particle number concentration in respective size bin.

\section{Results and discussions}

This section is divided into two parts. The first part provides discussion of measured particle size distributions on three 
typical NPF days. Air mass transport pathways and parameters that favour the formation of new particles at the SORPES site will be investigated. The second part focuses on the numerical simulation of observed NPF events. A further detailed analysis of particle formation and following growth will be presented.

\subsection{Observations and data analysis}

Summer marks the season with frequent NPF events at the SORPES site, especially in the year of 2013 (Qi et al., 2015). From June to August 2013, 50 NPF events were detected during the 76-day measurement period when DMPS functioned normally, resulting in particle formation probability of $66 \%$. Among the observed NPF events, three representative cases were identified according to the retroplumes calculated based on the Lagrangian dispersion model HYSPLIT (Hybrid Single Particle Lagrangian Integrated Trajectory Model) following the method developed by Ding et al. (2013c). These selected NPF days are 22 June, 10 July and 22 August 2013, when the site was dominantly influenced by air masses from the YRD region, South China, and mixed ocean and continental areas, respectively (Fig. 2).

On 22 June 2013, a clear banana-shaped particle size distribution was captured by the DMPS in the morning (09:0011:00 LT, Fig. 3). According to the DMPS observations, the number concentration of particles with diameter ranging from 6 to $30 \mathrm{~nm}$ reached up to $10000 \mathrm{~cm}^{-3}$ around 10:00 LT. The formation rate of $6 \mathrm{~nm}$ particles, namely $J_{6}$ calculated following Eq. (2), was $7.6 \mathrm{~cm}^{-3} \mathrm{~s}^{-1}$. It was generally comparable to those typically observed elsewhere in China, for instance, $0.97-10.2 \mathrm{~cm}^{-3} \mathrm{~s}^{-1}$ in Hong Kong $\left(J_{5.5}\right)$ (Guo et al., 2012). The diurnal variations of measured number size distribution and relevant trace gases are demonstrated in Fig. 3 . This NPF event featured a large background particle loading with $\mathrm{PM}_{2.5}$ mass concentration exceeding $50 \mu \mathrm{g} \mathrm{m}^{-3}$ because the air mass was lingering over city clusters in the YRD region before approaching the SORPES station, as shown in Fig. 2a. Dense particle emissions from the rapidly urbanized and industrialized YRD region (Fig. 2e) corresponded to a high condensation sink of $4.2 \times 10^{-2} \mathrm{~s}^{-1}$, close to those typically observed in other urban areas in China (Gao et al., 2012; Xiao et al., 2015). For the same reason, influenced by the emissions in the YRD region (Fig. 2d), $\mathrm{SO}_{2}$ concentration was observed to be $20-30 \mathrm{ppb}$, considerably higher than the normally observed level at the site, which is less than $10 \mathrm{ppb}$ during summertime (Ding et al., 2013a). High concentration of $\mathrm{O}_{3}$ and increasing radiation intensity were indicative of active ozone photolysis, and production of $\mathrm{OH}$ radicals, rapid gas-phase oxidation of $\mathrm{SO}_{2}$ by $\mathrm{OH}$ radical and accumulation of gaseous sulfuric acid are expected, leading to the onset of NPF despite the high level of condensation sink. The subsequent growth was fast, with a $\mathrm{GR}_{6-30}$ (growth rate from 6 to $30 \mathrm{~nm}$ ) of $12.6 \mathrm{~nm} \mathrm{~h}^{-1}$. Accumulating sulfuric acid with increasing ozone concentration might be one contributor. In
Table 2. Formation rate of $6 \mathrm{~nm}$ particles $\left(J_{6}\right)$, and particle growth rates from 6 to $30 \mathrm{~nm}\left(\mathrm{GR}_{6-30}\right)$ and condensation sink (CS) of three NPF events based on DMPS measurements and numeric modelling*.

\begin{tabular}{llrrr}
\hline Date & $\begin{array}{r}J_{6} \\
\left(\mathrm{~cm}^{-3} \mathrm{~s}^{-1}\right)\end{array}$ & $\begin{array}{r}\mathrm{GR}_{6-30} \\
\left(\mathrm{~nm} \mathrm{~h}^{-1}\right)\end{array}$ & $\begin{array}{r}\mathrm{CS} \\
\left(10^{-2} \mathrm{~s}^{-1}\right)\end{array}$ \\
\hline Case1 & 22 June 2013 & $7.6(9.3)$ & $12.6(6.9)$ & 4.2 \\
Case2 & 10 July 2013 & $1.2(1.6)$ & $13.5(10.7)$ & 3.2 \\
Case3 & 22 August 2013 & $3.4(10.0)$ & $15.7(2.3)$ & 1.9 \\
\hline * Values out of parentheses are observations and those in parentheses represent the
\end{tabular}
corresponding model results.

addition, the presence of aromatic-related oxidation products from residential and industrial combustion in the YRD region could also substantially enhance particle formation and subsequent growth by absorption or heterogeneous reactions (R. Y. Zhang et al., 2004; Y. Liu et al., 2008).

On 10 July when the air masses mostly came from the densely wooded area in South China, NPF had a much lower rate than on 22 June, yet a slightly faster particle growth rate (Table 2). Previous investigations have revealed that overall GR is correlated with the rate of terpenes reactions with atmospheric photochemical oxidants, highlighting the importance of biogenic VOCs in the particle growth process (e.g. Boy et al., 2003; Kulmala et al., 2004a). During the QUEST (Quantification of Aerosol Nucleation in the European Boundary Layer) field campaign in Hyytiälä, Finland, recorded particle growth rates during NPF events correlated notably with gas-phase monoterpene concentrations, indicating that the oxidation products from biogenic VOCs may dominate particle growth (Laaksonen et al., 2008; YliJuuti et al., 2011). The positive correlation between freshly formed particle growth rates and monoterpenes and their oxidation rates by ozone was also verified in Hong Kong, China (Guo et al., 2012). Figure $2 \mathrm{f}$ presents the spatial distribution of monoterpene emission rates during summertime across China calculated by the MEGAN model ( $\mathrm{Li}$ et al., 2012). It is obvious that monoterpene emission is overwhelmingly intensive in South China, which is covered by large areas of broadleaf forests and shrubs. It is plausible that air masses passed over biogenic VOC-rich regions were saturated with sufficiently low-volatility oxidation products, which enhanced the observed particle growth. The simulation results from the WRF-Chem model supported this view. Modelled isoprene and terpene concentrations were 1.2 and $0.15 \mathrm{ppb}$ at the SORPES site during NPF on 10 July, 150 and $50 \%$ higher than the corresponding values on 22 June. Besides, lower pre-existing particle loading is another cause of faster growth due to less particle surface area for vapour condensation.

Another NPF event, characterized by mixed marine and continental air masses, occurred on 22 August. Because of relatively clean air from the ocean and high wind speed of around $8 \mathrm{~m} \mathrm{~s}^{-1}, \mathrm{PM}_{2.5}$ and $\mathrm{SO}_{2}$ concentrations were un- 

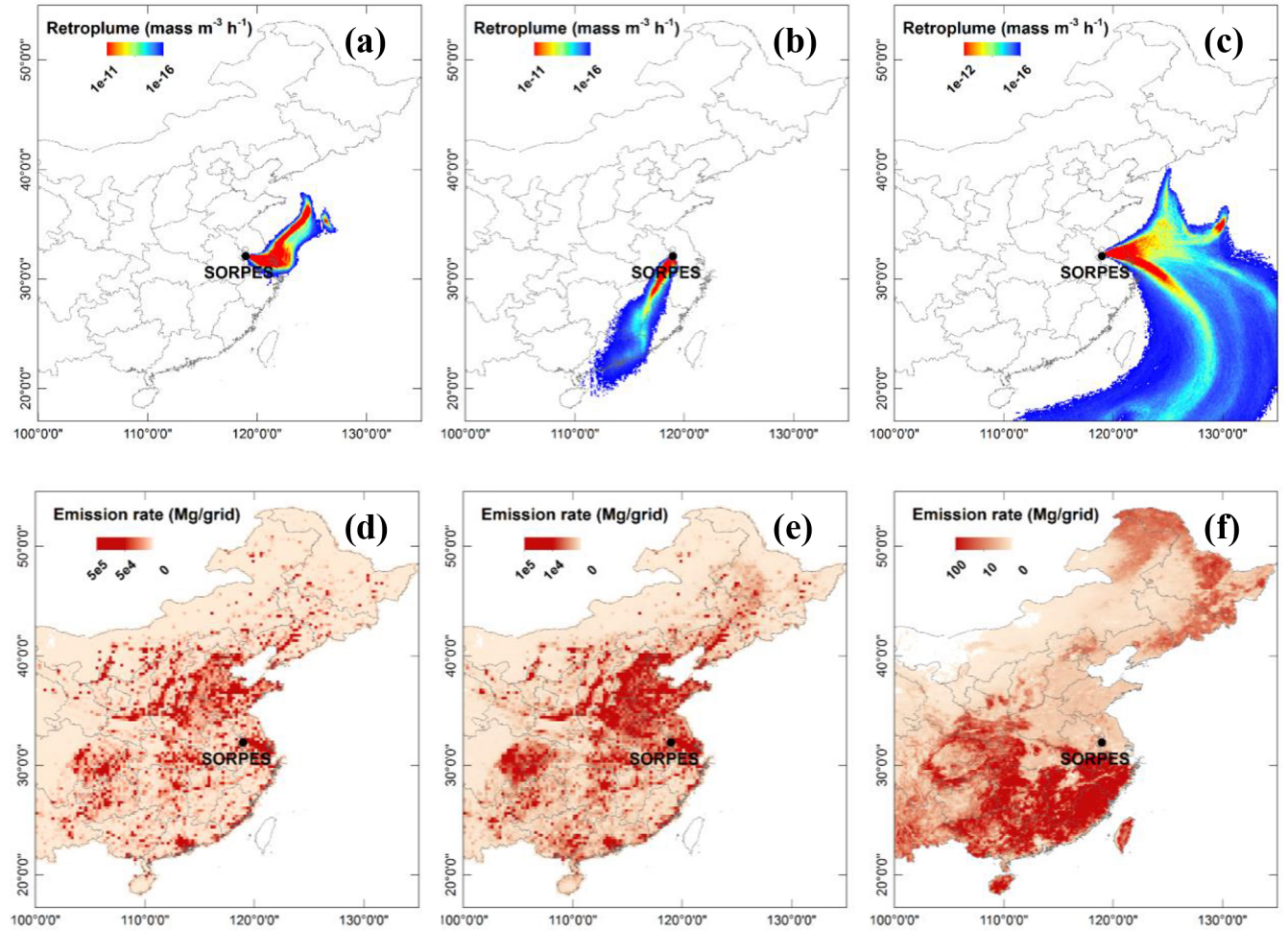

Figure 2. Retroplume (footprint residence time) showing transport pathways of air masses measured at the SORPES site for 22 June (a), 10 July (b) and 22 August (c). Spatial distributions of anthropogenic $\mathrm{SO}_{2}(\mathbf{d})$, primary $\mathrm{PM}_{2.5}$ (e) and biogenic monoterpene (f) emission rates.
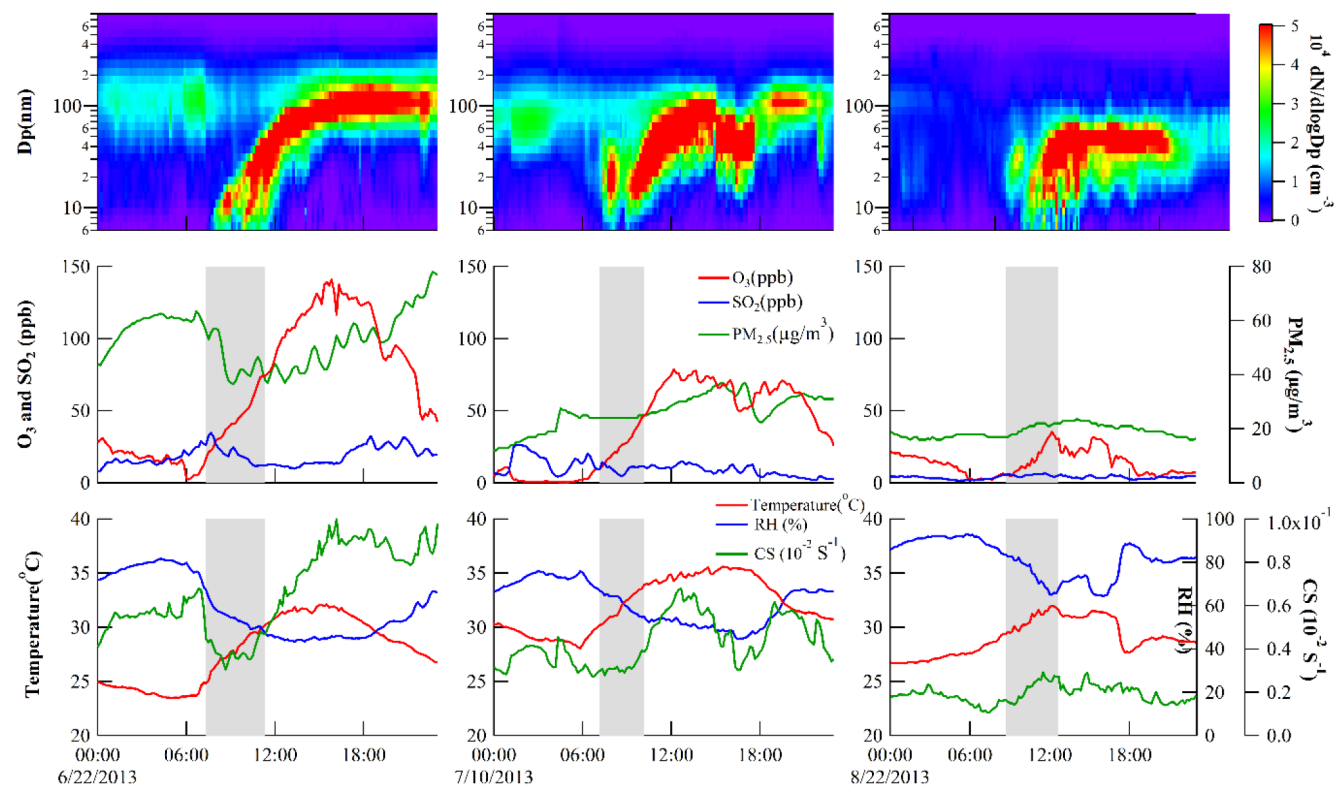

Figure 3. Measured diurnal variations of particle size distributions (upper panel), concentrations of $\mathrm{SO}_{2}, \mathrm{O}_{3}$ and $\mathrm{PM}_{2.5}$ (middle panel), and meteorological conditions and condensation sink (bottom panel) during the three NPF days. Grey boxes show the time span of NPF events.

usually low, only $11.0 \mu \mathrm{g} \mathrm{m}^{-3}$ and $2.8 \mathrm{ppb}$ when the NPF event took place. Accordingly, the condensation sink fell to $1.9 \times 10^{-2} \mathrm{~s}^{-1}$. Existing measurements and analysis con- cluded that the main obstacle for the initial onset of NPF at the SORPES site is condensation sink, since $\mathrm{SO}_{2}$ concentration is always high and there tends to be enough solar radi- 
Table 3. Statistical analysis of the simulated hourly $2 \mathrm{~m}$ temperature and $10 \mathrm{~m}$ wind speed versus the ground observations at the SORPES station.

\begin{tabular}{llrr}
\hline Date & Index* & $\begin{array}{r}2 \mathrm{~m} \text { temperature } \\
\left({ }^{\circ} \mathrm{C}\right)\end{array}$ & $\begin{array}{r}10 \mathrm{~m} \text { wind speed } \\
\left(\mathrm{m} \mathrm{s}^{-1}\right)\end{array}$ \\
\hline \multirow{2}{*}{ 22 June } & MB & -0.33 & 0.80 \\
& RMSE & 1.29 & 1.63 \\
\hline \multirow{2}{*}{ 10 July } & MB & -1.07 & -0.77 \\
& RMSE & 1.34 & 1.18 \\
\hline \multirow{2}{*}{22 August } & MB & 0.19 & 0.17 \\
& RMSE & 1.38 & 1.27 \\
\hline
\end{tabular}

* MB and RMSE refer to mean bias and root mean square error respectively.

ation as well (Herrmann et al., 2014). So, even though the $\mathrm{SO}_{2}$ concentration was fairly low during that day, a fairly small condensation sink could trigger the onset of this NPF event. The nuclei growth rate, $\mathrm{GR}_{6-30}$, was estimated to be $15.7 \mathrm{~nm} \mathrm{~h}^{-1}$. On the one hand, humid air mass transported from the ocean might have favoured the particle growth due to that high humidity could enhance the uptake and oxidation of $\mathrm{SO}_{2}$ and also facilitate the transformation of gaseous nitric acid to particulate ammonium nitrate (Hildemann et al., 1984; Rattigan et al., 2000). As displayed in Fig. 3, the measured relative humidity (RH) was over $80 \%$ when the NPF began. On the other hand, the sampling site was also partly influenced by the air masses from the YRD region (Fig. 2c), which means that anthropogenic VOCs and oxidation products with low volatility might also exert a notable impact on particle growth.

\subsection{Simulations of NPF events}

To shed further light on NPF processes at the SORPES station, comprehensive simulations were performed by combining the WRF-Chem regional atmospheric transport model and the MALTE-BOX model. Measurements of meteorological fields, trace gases and aerosol characteristics from the SORPES station are input to the box model. In the meantime, input also includes the concentrations of gaseous organic compounds from the WRF-Chem regional model (see Table 1). The simulations were conducted for the aforementioned three NPF days.

\subsubsection{Evaluation of simulations by WRF-Chem model}

Meteorological conditions play an important role in transport, diffusion and chemical reactions in the atmosphere. Simulated hourly $2 \mathrm{~m}$ temperature and $10 \mathrm{~m}$ wind speed were evaluated using hourly temperature and relative humidity observations at the SORPES station. Statistical analysis of model performance for the three NPF days are listed in Table 3, including mean bias (MB) and root mean square er- ror (RMSE). Generally, the model reproduced the observed $2 \mathrm{~m}$ temperature and $10 \mathrm{~m}$ wind. As mentioned, modelled VOC concentrations, which are vital for NPF simulation, are included as an input field in the MALTE-BOX model. Although there was no VOC measurement during the summer of 2013, the SORPES site and the Environmental Monitoring Centre of Jiangsu Province $\left(118^{\circ} 47^{\prime} \mathrm{E}, 32^{\circ} 4^{\prime} \mathrm{N}\right)$ were equipped with GC/MS (gas chromatography/mass spectrometry) in the summer of 2014. In order to evaluate the model's performance in simulating VOC concentrations, we conducted another WRF-Chem run for the August of 2014 and then compared the model results with corresponding observations. The comparison of alkene, aromatic and isoprene concentrations in Fig. 4a-c illustrates that WRF-Chem is capable of reproducing the magnitude and temporal variations of VOC concentration originating from both anthropogenic and biogenic sources. Specifically, modelled results tend to underestimate alkene concentration but overpredict aromatic level with normalized mean bias of -11 and $20 \%$, similar to previous simulations for Shanghai (Tie et al., 2013). There still exist substantial uncertainties in China's anthropogenic VOC emission inventory, particularly speciated estimations, which was ascribed to uncertainties in the activity data, limited direct experiments on emission factors and source profiles (Wei et al., 2008; Zheng et al., 2009). Large biases in model-predicted aromatic level are expectable since it is mainly emitted from petrochemical plants, gasoline vehicle and biomass burning with greater uncertainties in activity level estimation (Liu et al., 2008). In terms of biogenic VOCs, simplification in vegetation classification and numerical descriptions, limited understanding of controlling factors could introduce biases in modelled levels of BVOCs (Guenther, 2013). Given these uncertainties, the gaps between simulation and observations in Fig. $4 \mathrm{a}-\mathrm{c}$ are acceptable. As for simulated biogenic terpenes, whose oxidation products have low vapour pressures similar to sulfuric acid and condense onto aerosol surfaces, the spatial patterns in the morning of the aforementioned three NPF days showed great differences (Fig. 4d-f). During the first and third NPF cases, prevailing easterly winds did not bring much biogenic VOCs since biogenic emissions are most intensive in the southern part of China. By contrast, on 10 July when the air temperature was getting higher and southwesterly winds dominated, enhanced biogenic emissions and the shift in wind direction led to the fact that the modelled terpene concentrations at the SORPES station were almost two times those in the other two NPF days.

\subsubsection{MALTE-BOX simulations}

Figure 5 shows the variations of modelled particle number size distributions during the three NPF days. The model system does reproduce the occurrence of these three NPF events although they were under distinct meteorological conditions and affected by entirely different potential source 

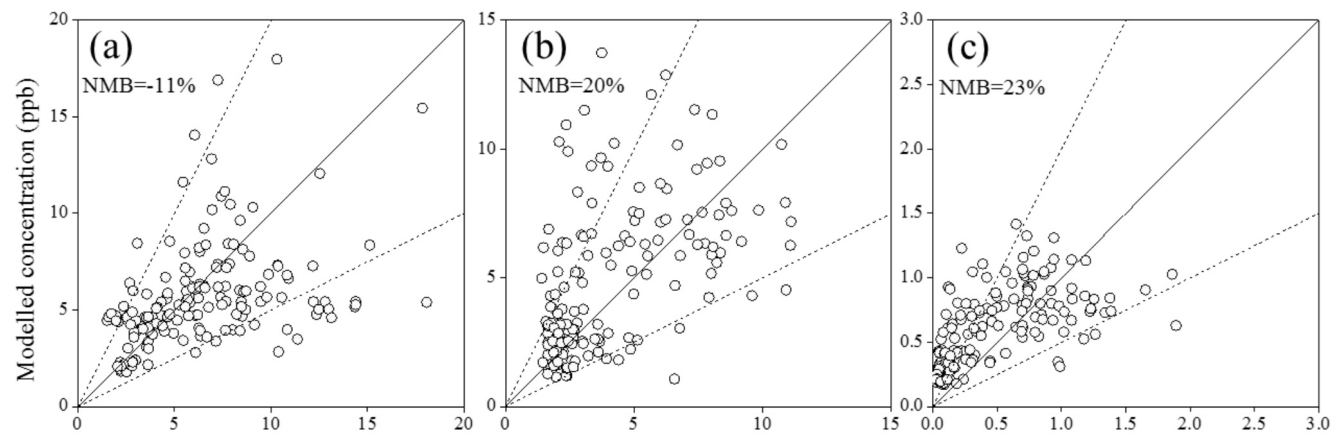

Observed concentration (ppb)

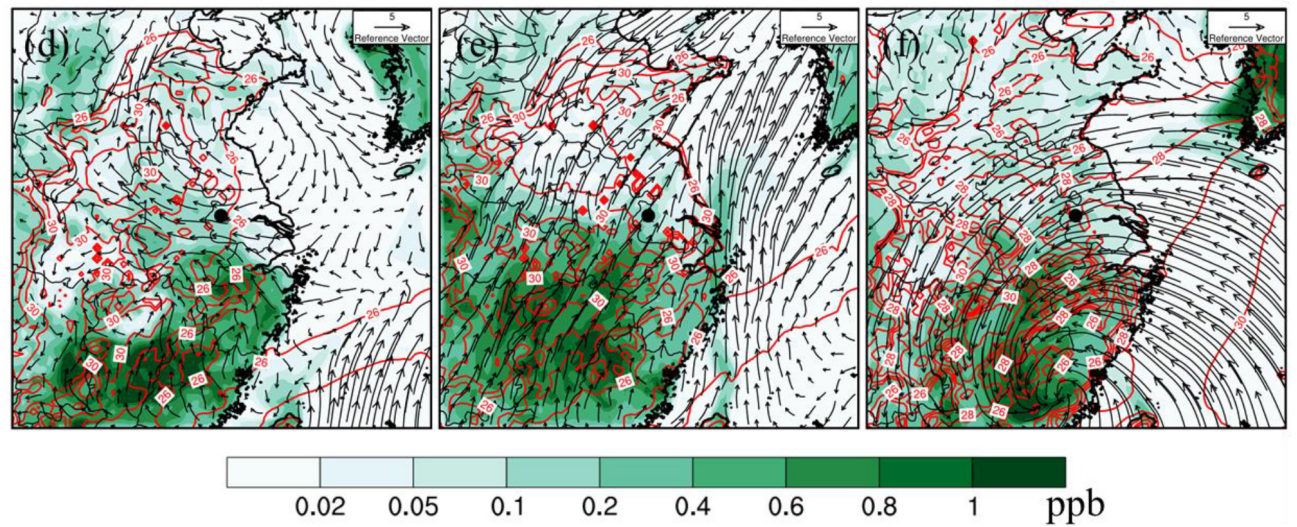

Figure 4. Scatter plots of observed and simulated alkene (a) aromatic (b) and isoprene (c) concentrations (NMB represents the normalized mean bias) in August 2014. The solid 1:1 lines and dashed 1:2 and 2:1 lines are shown for reference. Spatial distributions of terpene concentrations at 09:00 LT on 22 June (d), 10 July (e) and 22 August (f), 2013. The $2 \mathrm{~m}$ temperature is marked by red lines. The black dot marks the location of the SORPES station.

regions. On 22 June when measured air masses originated from the urbanized YRD region, the calculated onset of activation of freshly formed cluster to grow above the $6 \mathrm{~nm}$ line appeared around 08:30 LT. According to the diurnal pattern of simulated concentrations of gaseous compounds illustrated in Fig. 6, the $\mathrm{OH}$ radical level increased rapidly from $1 \times 10^{5}$ to $3 \times 10^{6} \mathrm{~cm}^{-3}$ just after sunrise, promoting the gaseous oxidation of $\mathrm{SO}_{2}$ in the atmosphere and subsequent accumulation of sulfuric acid from nearly zero to around $5 \times 10^{6} \mathrm{~cm}^{-3}$. Simultaneously, the pre-existing particle concentration dropped due to the boundary layer evolution (Fig. 3). The continuously growing sulfuric acid concentration and decreasing condensation sink jointly led to this fast NPF event. Simulated $J_{6}$ was $9.3 \mathrm{~cm}^{-3} \mathrm{~s}^{-1}$, slightly higher than the observed value of $7.6 \mathrm{~cm}^{-3} \mathrm{~s}^{-1}$. Among different kinds of condensing vapours, sulfuric acid contributed most to the growth of newly formed particles. As demonstrated in Fig. 7, while considering the growth of particles less than $10 \mathrm{~nm}$ in diameter, sulfuric acid's contribution accounted for more than $50 \%$. The reason is that, influenced by air mass from the emission-intensive YRD region, $\mathrm{SO}_{2}$ was reaching up to $20 \mathrm{ppb}$ and the contribution of sulfuric acid on this day was much higher compared with the other 2 days and those published in earlier studies (Boy et al., 2003, 2008b).
$\mathrm{GR}_{6-30}$ was simulated to be $6.9 \mathrm{~nm} \mathrm{~h}^{-1}$, about half of that derived from measurements. Overestimated newly formed clusters might be one reason for smaller simulated $\mathrm{GR}_{6-30}$. Another, as described before, is that condensing vapours in the box model only included biogenic low-volatility compounds. However, aromatic-related oxidation products have been suspected of contributing to particle growth, especially in polluted area like China (Zhang et al., 2004; Yue et al., 2010). Failing to characterize condensing vapour originating from anthropogenic organic compounds might be another cause of the underpredicted growth rate.

During the second NPF case, the $\mathrm{OH}$ radical concentration was mostly less than $1 \times 10^{6} \mathrm{~cm}^{-3}$. The production of sulfuric acid was expected to be relatively slow due to the simultaneous lower concentrations of both $\mathrm{SO}_{2}$ and $\mathrm{OH}$ radical. As demonstrated in Fig. 6, the concentration of sulfuric acid was approximately $3 \times 10^{5} \mathrm{~cm}^{-3}$ just when the NPF started, about one-tenth and one-seventh of the corresponding values on 22 June and 22 August, respectively. Nonetheless, prevailing southwesterly winds brought along terpenerich air masses. Some of the terpenes, such as alpha-pinene and limonene, feature significantly high yields of ELVOCs as well as SVOCs while reacting with ozone or $\mathrm{OH}$ radicals (Ehn et al., 2014; Jokinen et al., 2015). Such dense low- 

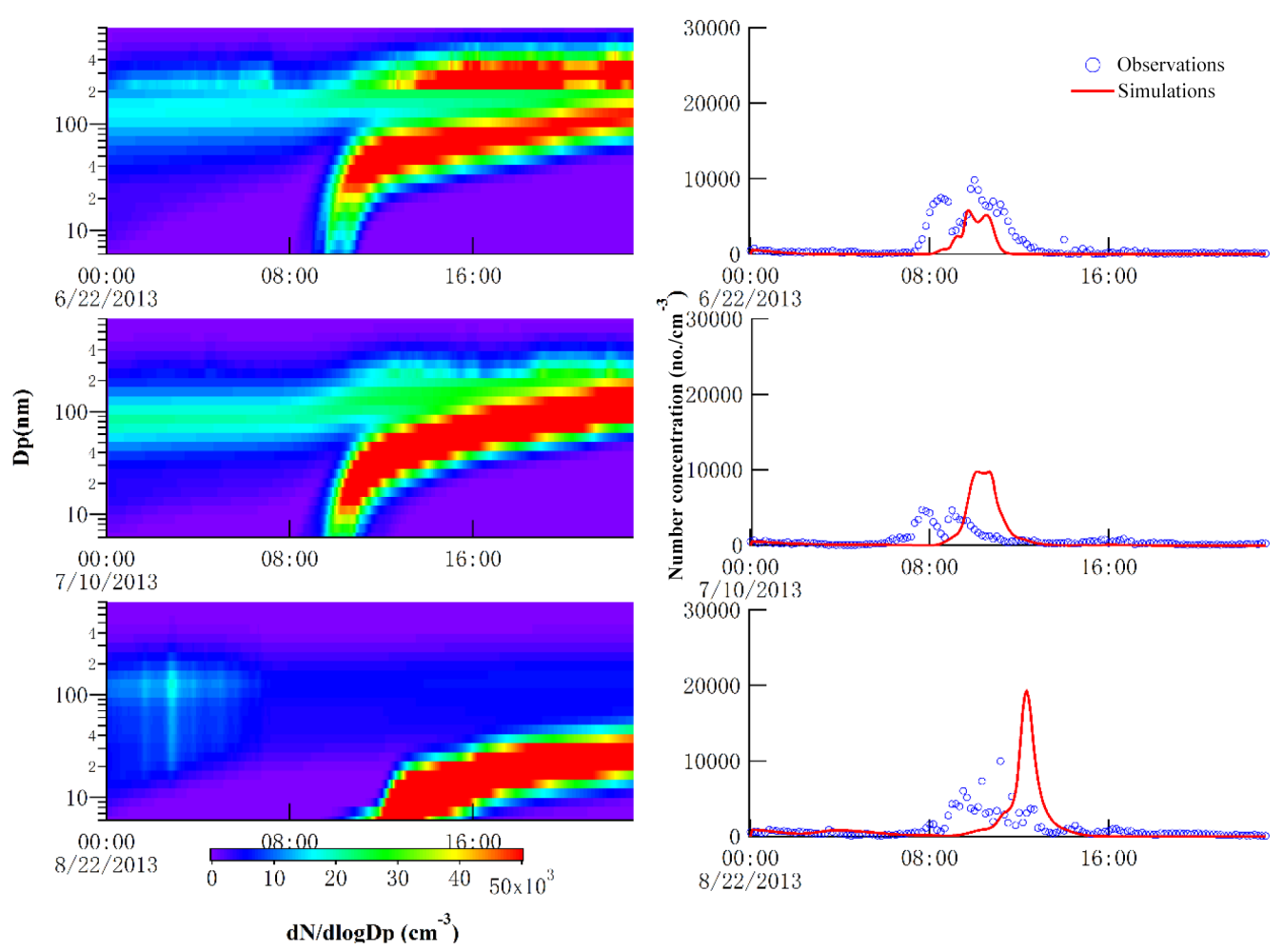

Figure 5. Modelled pattern of particle size distributions (left panel) and number concentrations of particles ranging from 6 to $10 \mathrm{~nm}$ during these three NPF days (right panel).

volatility oxidation products substantially enhanced the condensational growth of newly formed particles. The individual contributions from sulfuric acid, SVOCs and ELVOCs to growth of newly formed particles were quantified in Fig. 7, which indicated that biogenic low-volatility compounds overwhelmingly dominated in the very initial stage of cluster growth with contribution as high as $95 \%$, demonstrating a vital role of ELVOCs and SVOCs in this NPF event (Ehn et al., 2014). During this event, SVOC-induced condensational growth of small clusters was especially higher, which might be attributed to the fact that modelled SVOC concentrations increased dramatically shortly after the nucleation started and was almost ten times higher than those during the other two events.

Unlike during the first two NPF cases, the level of preexisting particles was unusually low during the third event because a strong wind from the ocean swept over East China. The clean air mass reduced the condensation sink (see Table 2), much lower than the values typically observed at the SORPES site before (Herrmann et al., 2014). Even though $\mathrm{SO}_{2}$ concentrations were pretty low, sulfuric acid accumulated remarkably and probably initiated this NPF event. As listed in Table 2, during Case 3 when the air mass originated partly over the Shanghai and surrounding city clusters, the model underpredicted the growth rate by nearly a factor of 7 and overestimated the particle formation rate by a factor of 3 .
This means that most probably anthropogenic low-volatility compounds not included in the model were contributing to the growth and decreased the surviving probability of the newly formed clusters in the model. It is completely opposite for Case 2 when the air mass did not originate from strongly anthropogenic-influenced areas and the model outcome was in good agreement with the measurements.

\subsubsection{Discussions and uncertainties}

Though the model succeeded in the prediction of DMPSmeasured NPF occurrence, the simulated activation of NPF was about 1 hour later than the observations. Considering the number concentration in the size range $6-10 \mathrm{~nm}\left(N_{6-10}\right)$ as the newly formed particles, the model shows a distinct underestimation at the beginning of the NPF events (Fig. 5). As mentioned in Sect. 2, we assumed the kinetic mechanism in the MALTE-BOX. Nonetheless, chamber and in situ experiments suggested that monoterpene oxidation products could cluster directly with a single sulfuric acid molecule under ambient conditions and that the interaction between organic and sulfuric acids likely leads to a reduced nucleation barrier (R. Y. Zhang et al., 2004; Schobesberger et al., 2013). Furthermore, according to the simulation, the production of ELVOCs and SVOCs was mainly initialized by the reactions between monoterpene and ozone. It has been recognized that NPF events tend to be strongly associated with the monoter- 


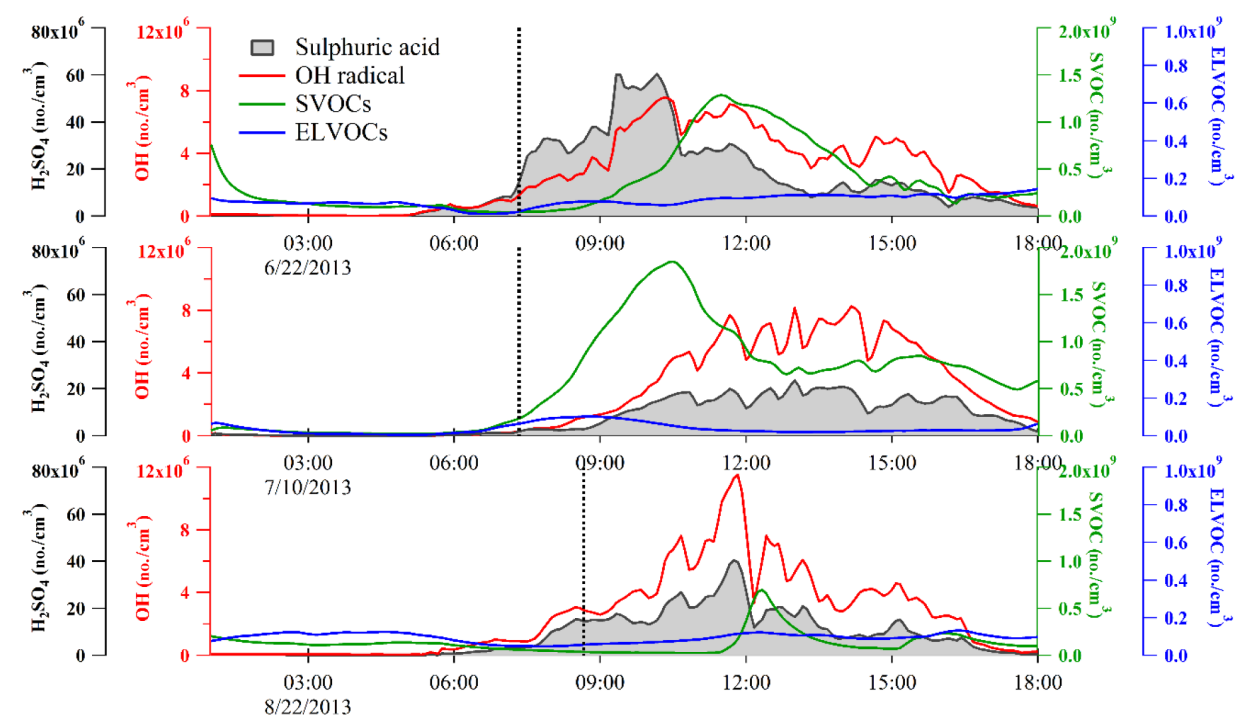

Figure 6. Time series of several gas concentrations $\left(\mathrm{cm}^{-3}\right)$ during the three selected NPF days. Sulfuric acid, OH radical, SVOCs and ELVOCs are marked in grey area, red, green and blue lines, respectively. Dashed lines show the onset time of NPF according to DMPS measurements for reference.

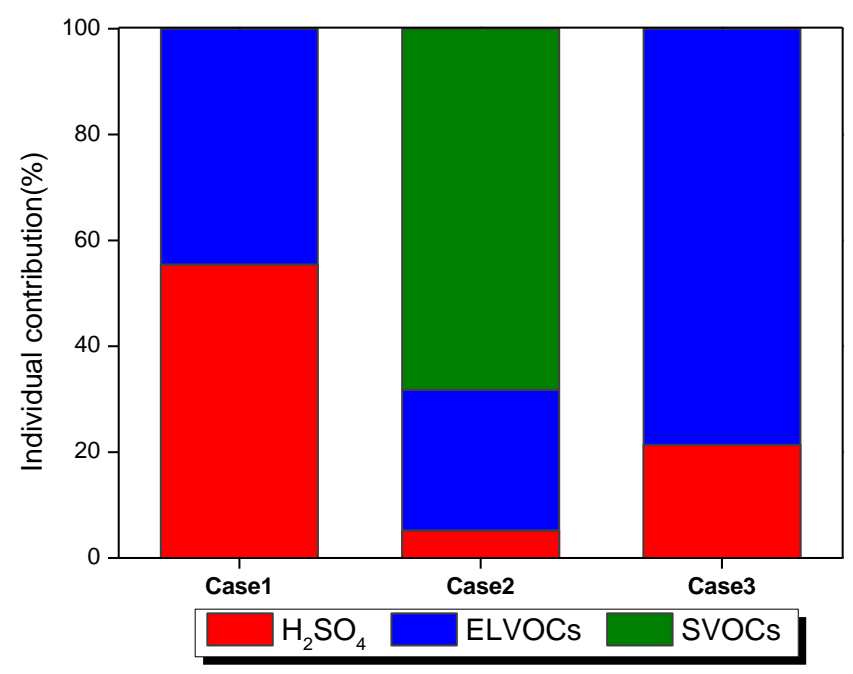

Figure 7. Contributions from three kinds of condensing vapours to growth of particle less than $10 \mathrm{~nm}$ during NPF events on 22 June (Case 1), 10 July (Case 2) and 22 August (Case 3). Sulfuric acid, SVOCs and ELVOCs are marked in red, green and blue bars, respectively.

pene oxidation products by ozone in both remote and urban environments (Laaksonen et al., 2008; Guo et al., 2012). Thus, there was a good chance that the ELVOCs played an important part in the NPF processes considered here. As presented in Fig. 6, a considerable amount of ELVOCs accumulated before the modelled NPF occurred and during the observed NPF events. The time shifts of the starting times is consistent with the hypothesis that organic vapours may play a key role in the particle formation process (Paasonen et al., 2009; Metzger et al., 2010). Figure 8a shows the dependence of measurement-derived $J_{6}$ on modelled gaseous sulfuric acid and ELVOC concentrations; $6 \mathrm{~nm}$ NPF rates, even under the same sulfuric acid concentration, were substantially enhanced by the presence of ELVOCs. It is noteworthy that formation rates of $6 \mathrm{~nm}$ particles, not nucleation rates, are available here due to the limitation of instruments. It is hard to identify which process is most promoted by ELVOCs, the particle formation or the early condensational growth. Metzger et al. (2010) attempted to disentangle the influence of organic oxidation products in particle formation and suggested an overall dependency on the formation rate of $\mathrm{H}_{2} \mathrm{SO}_{4}$ and organic oxidation products with the lowest volatility (NucOrg) as follows:

$J_{1.5}=k \times\left[\mathrm{H}_{2} \mathrm{SO}_{4}\right]^{1.0}[\mathrm{NucORG}]^{0.8}$,

where $J_{1.5}$ is new particle formation rate of $1.5 \mathrm{~nm}$ cluster; $k$ represents a pre-factor which is recommended to be $7.2 \pm 1.4 \times 10^{-13} \mathrm{~cm}^{3} \mathrm{~s}^{-1}$ in Metzger et al. (2010); $\left[\mathrm{H}_{2} \mathrm{SO}_{4}\right]$ and [NucOrg] refer to the concentration of sulfuric acid and low-volatility organic oxidation products that can participate in the particle formation process, respectively. By assuming that NucOrg is part of the ELVOCs in the present work, we examined the relationships between measured particle formation rate with $\left[\mathrm{H}_{2} \mathrm{SO}_{4}\right]^{1.0}[\text { ELVOCs }]^{0.8}$ and compared it with $\left[\mathrm{H}_{2} \mathrm{SO}_{4}\right]^{2}$ in Fig. 8b-c. The better representation and correlation of the latter provides further evidence for an involvement of ELVOCs in the formation and condensational growth of particles up to $6 \mathrm{~nm}$.

In terms of the condensational growth of freshly formed particles, ambient low-volatility compounds are predominant contributors - in particular, with semi-volatile and possibly 

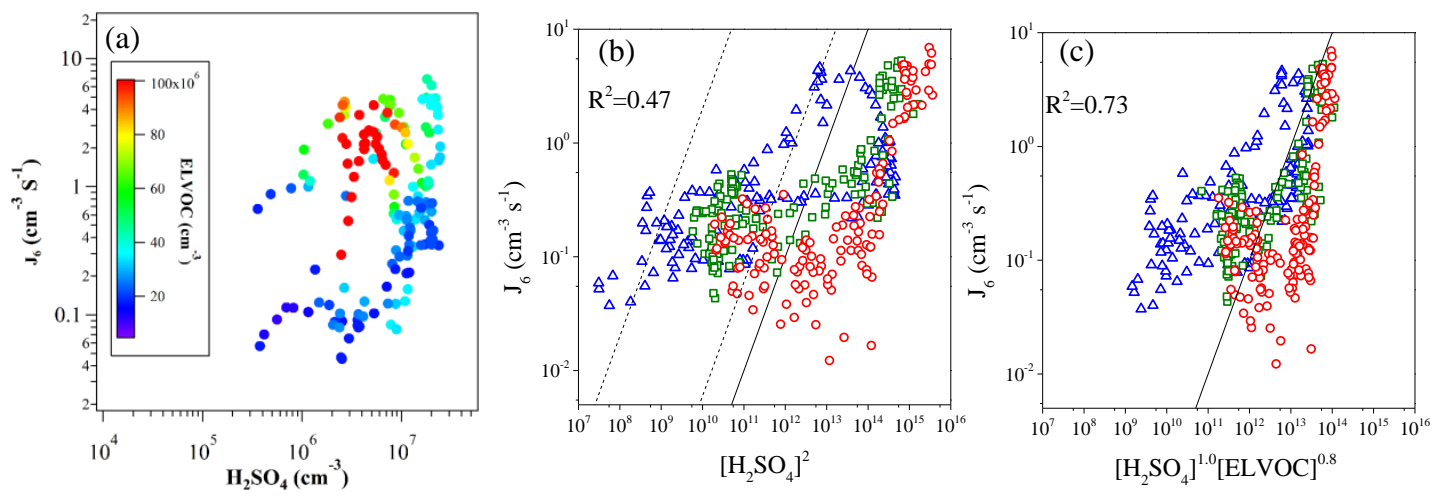

Figure 8. Correlations of estimated new particle formation rates $\left(J_{6}\right)$ from DMPS measurements with modelled gaseous sulfuric acid and ELVOC concentrations for event days between 06:00 and 16:00 (a). Scatter plots of new particle formation rate $J_{6}$ estimated from measurements with modelled sulfuric acid and ELVOC concentrations (b-c), in which red, blue and green markers refer to 22 June, 10 July and 22 August, respectively. The square of correlation coefficients $\left(R^{2}\right)$ are labelled in (b) and (c). Black solid lines denote $y=10^{-13} x$. Dashed lines show $y=2.2 \times 10^{-10} x$ (left) and $y=6.0 \times 10^{-13} x$ (right) for reference in (b).

non-volatile organic matters generating from a complex series of photochemical reactions (Kroll and Seinfeld, 2008). In the present work, the model notably underestimates the nuclei condensational growth $\left(\mathrm{GR}_{6-30}\right)$ for Case 1 and Case 3 compared with the corresponding observations, whereas the observation and simulation were comparable for Case 2 (Table 2). These differences could partly be due to the fact that here we only took oxidation products for certain selected organic compounds into account as sources of condensable vapours. When the experimental site was substantially influenced by intensive industrial activities and vehicle emissions from the YRD region in Case 1 and Case 3, reactive uptake and condensable secondary organic products from anthropogenic VOCs, which can accelerate particle growth (R. Y. Zhang et al., 2004b; Kroll et al., 2005; Volkamer et al., 2006), were partly missing in the present model. Regarding the impacts of biogenic VOCs, we found that ELVOCs and SVOCs remarkably contributed to particle condensational growth. Modelled contributions from ELVOCs, SVOCs and sulfuric acid demonstrated that, during these three NPF days, condensation of ELVOCs and SVOCs played an important role in the initial growth of particles less than $10 \mathrm{~nm}$. In particular, the contribution increased to over $90 \%$ on 10 July when the terpenes-rich air mass influenced the SORPES site.

The comprehensive modelling study on the observed NPF makes it possible to better understand NPF processes at the SORPES station. However, there remain many uncertainties in this modelling system, which need to be addressed in future work. Given the expensive computational cost, reactions of VOCs are represented by the lumped mechanism in the regional-scale WRF-Chem model. Relevant parameters cannot be precisely determined for one lumped class, while the MALTE-BOX model provides accurate information for each specific organic compound. The gaps between the two models concerning VOC classification would introduce un- certainties. Moreover, in the MALTE-BOX model, sulfuric acid tends to be underpredicted, which was demonstrated in both polluted urban environment and clean rural environment (Wang et al., 2013a; Zhou et al., 2014; Zhou et al., 2015). There are multiple reasons behind the systematic underestimation. It has been shown by field measurements, laboratory experiments and numeric simulation that Crigee Intermediates (CIs) or other derivatives are capable of accelerating the oxidation of $\mathrm{SO}_{2}$ into $\mathrm{SO}_{3}$ (Hatakeyama and Akimoto, 1994; Kurten et al., 2011; Boy et al., 2013). These reactions have been incorporated in the MALTE-BOX model but would need further investigations concerning the reactions rates and other important reaction parameters (e.g. thermal lifetimes of CIs, pressure dependency). In addition, owing to the significantly incomplete knowledge of HONO sources, in particular during daytime, it has not yet been possible to simulate realistic HONO levels using current models (Elshorbany et al., 2014; Czader et al., 2015). The lack of HONO measurement input to the model might also result in an underestimation of sulfuric acid, especially with dramatically increasing traffic emissions during the rush hours (Wang et al., 2013b). For instance, in the first case, the air masses were carrying on more anthropogenic pollutants from the emissions-intensive YRD region, and the sulfuric acid concentrations and particle formation rates are more likely to be underpredicted. Last but not least, we adopted a mandatory value for the kinetic coefficient, which includes the probability that a collision of two molecules results in the formation of a stable critical cluster, as well as all other important details concerning the particle formation process such as temperature and humidity. This condition-dependent coefficient needs to be resolved in further modelling work on the basis of more in situ and laboratory experiments. 


\section{Conclusions}

This study combines the regional chemical transport model and box model to investigate atmospheric NPF and the subsequent nuclei condensational growth at the SORPES site in Nanjing, China. This combination makes it possible to simulate chemical and aerosol dynamical processes. Three NPF cases, during which entirely different potential source regions influenced the experimental site, were successfully reproduced by the modelling system. When the site was predominately influenced by air masses from city clusters in the YRD region on 22 June 2013, despite a high condensation sink, the NPF event featured a fast NPF rate due to the continuously accumulating sulfuric acid. Under the circumstance that biogenic VOC-rich air masses dominated, rapid growth of freshly formed particles was detected on 10 July 2013, which was predominately attributed to the low-volatility oxidation products of terpenes. Air masses from marine origin could lead to the relatively low condensation sink on $22 \mathrm{Au}-$ gust 2013, thereby facilitating the occurrence of NPF event. On the basis of measurements and the corresponding modelling, we infer the controlling factors of the selected three NPF events, and these were mostly associated with sulfuric acid accumulation and low condensation sink. The comparison with the observations suggested that low-volatility organic compounds, including both SVOCs and ELVOCs, played a substantial role in the initial condensational growth of newly formed particles, particularly when the station was influenced by air masses originating from South China. In addition, anthropogenic VOCs and the following photochemical oxidation produce a considerable amount of condensable compounds, exerting a significant impact on particle growth in the emission-intensive YRD region. Although some inadequacies still remain, such as the inclusion of anthropogenic non-volatile organic compounds as condensable vapours, the comprehensive modelling work provides a better insight of NPF processes.

Acknowledgements. This work was supported by the National Natural Science Foundation of China (D0512/41422504, D0510/41505109, D0512/91544231 and D512/41305123), the National Key Technology Research and Development Program (2014BAC22B02) and the Science and Technology Support Program of Jiangsu Province (SBE2014070928). Part of this work was supported by the Jiangsu Provincial Science Fund for Distinguished Young Scholars awarded to A. J. Ding (No. BK20140021) and by the Academy of Finland projects $(1118615,139656)$ and the European Commission via ERC Advanced Grant ATM-NUCLE. We also acknowledge financial support from the Helsinki University Centre for Environment (HENVI). The numerical calculations in this paper have been done on the Blade cluster system in the High Performance Computing \& Massive Data Center (HPC\&MDC) of the School of Atmospheric Science, Nanjing University.

Edited by: S. M. Noe

\section{References}

Almeida, J., Schobesberger, S., Kurten, A., Ortega, I. K., Kupiainen-Maatta, O., Praplan, A. P., Adamov, A., Amorim, A., Bianchi, F., Breitenlechner, M., David, A., Dommen, J., Donahue, N. M., Downard, A., Dunne, E., Duplissy, J., Ehrhart, S., Flagan, R. C., Franchin, A., Guida, R., Hakala, J., Hansel, A., Heinritzi, M., Henschel, H., Jokinen, T., Junninen, H., Kajos, M., Kangasluoma, J., Keskinen, H., Kupc, A., Kurten, T., Kvashin, A. N., Laaksonen, A., Lehtipalo, K., Leiminger, M., Leppa, J., Loukonen, V., Makhmutov, V., Mathot, S., McGrath, M. J., Nieminen, T., Olenius, T., Onnela, A., Petaja, T., Riccobono, F., Riipinen, I., Rissanen, M., Rondo, L., Ruuskanen, T., Santos, F. D., Sarnela, N., Schallhart, S., Schnitzhofer, R., Seinfeld, J. H., Simon, M., Sipila, M., Stozhkov, Y., Stratmann, F., Tome, A., Trostl, J., Tsagkogeorgas, G., Vaattovaara, P., Viisanen, Y., Virtanen, A., Vrtala, A., Wagner, P. E., Weingartner, E., Wex, H., Williamson, C., Wimmer, D., Ye, P. L., Yli-Juuti, T., Carslaw, K. S., Kulmala, M., Curtius, J., Baltensperger, U., Worsnop, D. R., Vehkamaki, H., and Kirkby, J.: Molecular understanding of sulphuric acid-amine particle nucleation in the atmosphere, Nature, 502, 359-363, doi:10.1038/Nature12663, 2013.

Boy, M., Rannik, U., Lehtinen, K. E. J., Tarvainen, V., Hakola, H., and Kulmala, M.: Nucleation events in the continental boundary layer: Long-term statistical analyses of aerosol relevant characteristics, J. Geophys. Res. Atmos., 108, 4667, doi:10.1029/2003jd003838, 2003.

Boy, M., Hellmuth, O., Korhonen, H., Nilsson, E. D., ReVelle, D., Turnipseed, A., Arnold, F., and Kulmala, M.: MALTE - model to predict new aerosol formation in the lower troposphere, Atmos. Chem. Phys., 6, 4499-4517, doi:10.5194/acp-6-4499-2006, 2006.

Boy, M., Bonn, B., Kazil, J., Lovejoy, N., Turnipseed, A., Greenberg, J., Karl, T., Mauldin, L., Kusciuch, E., and Smith, J.: Relevance of several nucleation theories in different environments, in: Nucleation and Atmospheric Aerosols, Springer, 87-91, 2007.

Boy, M., Kazil, J., Lovejoy, E. R., Guenther, A., and Kulmala, M.: Relevance of ion-induced nucleation of sulfuric acid and water in the lower troposphere over the boreal forest at northern latitudes, Atmos. Res., 90, 151-158, 2008a.

Boy, M., Karl, T., Turnipseed, A., Mauldin, R. L., Kosciuch, E., Greenberg, J., Rathbone, J., Smith, J., Held, A., Barsanti, K., Wehner, B., Bauer, S., Wiedensohler, A., Bonn, B., Kulmala, M., and Guenther, A.: New particle formation in the Front Range of the Colorado Rocky Mountains, Atmos. Chem. Phys., 8, 15771590, doi:10.5194/acp-8-1577-2008, 2008b.

Boy, M., Mogensen, D., Smolander, S., Zhou, L., Nieminen, T., Paasonen, P., Plass-Dülmer, C., Sipilä, M., Petäjä, T., Mauldin, L., Berresheim, H., and Kulmala, M.: Oxidation of $\mathrm{SO}_{2}$ by stabilized Criegee intermediate ( $\mathrm{sCI}$ ) radicals as a crucial source for atmospheric sulfuric acid concentrations, Atmos. Chem. Phys., 13, 3865-3879, doi:10.5194/acp-13-3865-2013, 2013.

Carter, W. P. L.: Documentation of the SAPRC-99 chemical mechanism for VOC reactivity assessment, University of California, Riverside, CA, 446 pp., 1999.

Czader, B. H., Choi, Y., Li, X., Alvarez, S., and Lefer, B.: Impact of updated traffic emissions on HONO mixing ratios simulated for urban site in Houston, Texas, Atmos. Chem. Phys., 15, 12531263, doi:10.5194/acp-15-1253-2015, 2015. 
Damian, V., Sandu, A., Damian, M., Potra, F., and Carmichael, G. R.: The kinetic preprocessor KPP - a software environment for solving chemical kinetics, Comput. Chem. Eng., 26, 1567-1579, 2002.

Davidson, C. I., Phalen, R. F., and Solomon, P. A.: Airborne particulate matter and human health: A review, Aerosol Sci. Tech., 39, 737-749, doi:10.1080/02786820500191348, 2005.

Ding, A. J., Fu, C. B., Yang, X. Q., Sun, J. N., Zheng, L. F., Xie, Y. N., Herrmann, E., Nie, W., Petäjä, T., Kerminen, V.-M., and Kulmala, M.: Ozone and fine particle in the western Yangtze River Delta: an overview of $1 \mathrm{yr}$ data at the SORPES station, Atmos. Chem. Phys., 13, 5813-5830, doi:10.5194/acp-13-58132013, 2013a.

Ding, A. J., Fu, C. B., Yang, X. Q., Sun, J. N., Petäjä, T., Kerminen, V.-M., Wang, T., Xie, Y., Herrmann, E., Zheng, L. F., Nie, W., Liu, Q., Wei, X. L., and Kulmala, M.: Intense atmospheric pollution modifies weather: a case of mixed biomass burning with fossil fuel combustion pollution in eastern China, Atmos. Chem. Phys., 13, 10545-10554, doi:10.5194/acp-1310545-2013, 2013b.

Ding, A. J., Wang, T., and Fu, C. B.: Transport characteristics and origins of carbon monoxide and ozone in Hong Kong, South China, J. Geophys. Res.-Atmos., 118, 9475-9488, doi:10.1002/jgrd.50714, 2013c.

Ehn, M., Thornton, J. A., Kleist, E., Sipila, M., Junninen, H., Pullinen, I., Springer, M., Rubach, F., Tillmann, R., Lee, B., LopezHilfiker, F., Andres, S., Acir, I. H., Rissanen, M., Jokinen, T., Schobesberger, S., Kangasluoma, J., Kontkanen, J., Nieminen, T., Kurten, T., Nielsen, L. B., Jorgensen, S., Kjaergaard, H. G., Canagaratna, M., Dal Maso, M., Berndt, T., Petaja, T., Wahner, A., Kerminen, V. M., Kulmala, M., Worsnop, D. R., Wildt, J., and Mentel, T. F.: A large source of low-volatility secondary organic aerosol, Nature, 506, 476-479, doi:10.1038/Nature13032, 2014.

Eidels-Dubovoi, S.: Aerosol impacts on visible light extinction in the atmosphere of Mexico City, Sci. Total. Environ., 287, 213 220, doi:10.1016/S0048-9697(01)00983-4, 2002.

Ek, M. B., Mitchell, K. E., Lin, Y., Rogers, E., Grunmann, P., Koren, V., Gayno, G., and Tarpley, J. D.: Implementation of Noah land surface model advances in the National Centers for Environmental Prediction operational mesoscale Eta model, J. Geophys. Res. Atmos., 108, 8851, doi:10.1029/2002jd003296, 2003.

Elshorbany, Y. F., Crutzen, P. J., Steil, B., Pozzer, A., Tost, H., and Lelieveld, J.: Global and regional impacts of HONO on the chemical composition of clouds and aerosols, Atmos. Chem. Phys., 14, 1167-1184, doi:10.5194/acp-14-1167-2014, 2014.

Gao, J., Wang, T., Zhou, X. H., Wu, W. S., and Wang, W. $\mathrm{X}$.: Measurement of aerosol number size distributions in the Yangtze River delta in China: Formation and growth of particles under polluted conditions, Atmos. Environ., 43, 829-836, doi:10.1016/j.atmosenv.2008.10.046, 2009.

Gao, J., Chai, F. H., Wang, T., and Wang, W. X.: Particle number size distribution and new particle formation (NPF) in Lanzhou, Western China, Particuology, 9, 611-618, doi:10.1016/j.partic.2011.06.008, 2011

Gao, J., Chai, F. H., Wang, T., Wang, S. L., and Wang, W. X.: Particle number size distribution and new particle formation: New characteristics during the special pollution control period in Beijing, J. Environ. Sci.-China, 24, 14-21, doi:10.1016/S10010742(11)60725-0, 2012.
Grell, G. A. and Devenyi, D.: A generalized approach to parameterizing convection combining ensemble and data assimilation techniques, Geophys. Res. Lett., 29, 1693, doi:10.1029/2002g1015311, 2002.

Grell, G. A., Peckham, S. E., Schmitz, R., McKeen, S. A., Frost, G., Skamarock, W. C., and Eder, B.: Fully coupled "online" chemistry within the WRF model, Atmos. Environ., 39, 6957-6975, 2005.

Guenther, A.: Biological and chemical diversity of biogenic volatile organic emissions into the atmosphere, ISRN Atmos. Sci. 786290, doi:10.1155/2013/786290, 2013.

Guenther, A., Karl, T., Harley, P., Wiedinmyer, C., Palmer, P. I., and Geron, C.: Estimates of global terrestrial isoprene emissions using MEGAN (Model of Emissions of Gases and Aerosols from Nature), Atmos. Chem. Phys., 6, 3181-3210, doi:10.5194/acp-63181-2006, 2006.

Guo, H., Wang, D. W., Cheung, K., Ling, Z. H., Chan, C. K., and Yao, X. H.: Observation of aerosol size distribution and new particle formation at a mountain site in subtropical Hong Kong, Atmos. Chem. Phys., 12, 9923-9939, doi:10.5194/acp-12-99232012, 2012.

Guo, S., Hu, M., Zamora, M. L., Peng, J. F., Shang, D. J., Zheng, J., Du, Z. F., Wu, Z., Shao, M., Zeng, L. M., Molina, M. J., and Zhang, R. Y.: Elucidating severe urban haze formation in China, Proc. Natl. Acad. Sci. USA, 111, 17373-17378, doi:10.1073/pnas.1419604111, 2014.

Hatakeyama, S. and Akimoto, H.: Reactions of Criegee Intermediates in the Gas-Phase, Res. Chem. Intermediat., 20, 503-524, doi:10.1163/156856794x00432, 1994.

Herrmann, E., Ding, A. J., Kerminen, V.-M., Petää, T., Yang, X. Q., Sun, J. N., Qi, X. M., Manninen, H., Hakala, J., Nieminen, T., Aalto, P. P., Kulmala, M., and Fu, C. B.: Aerosols and nucleation in eastern China: first insights from the new SORPES-NJU station, Atmos. Chem. Phys., 14, 2169-2183, doi:10.5194/acp14-2169-2014, 2014.

Hildemann, L. M., Russell, A. G., and Cass, G. R.: Ammonia and nitric-acid concentrations in equilibrium with atmospheric aerosols - experiment vs theory, Atmos. Environ., 18, 17371750, 1984.

Hong, S. Y.: A new stable boundary-layer mixing scheme and its impact on the simulated East Asian summer monsoon, Q. J. R. Meteorol. Soc., 136, 1481-1496, doi:10.1002/Qj.665, 2010.

Huang, X., Song, Y., Zhao, C., Li, M. M., Zhu, T., Zhang, Q., and Zhang, X. Y.: Pathways of sulfate enhancement by natural and anthropogenic mineral aerosols in China, J. Geophys. Res. Atmos., 119, 14165-14179, doi:10.1002/2014jd022301, 2014.

Huang, X., Song, Y., Zhao, C., Cai, X. H., Zhang, H. S., and Zhu, T.: Direct Radiative Effect by Multicomponent Aerosol over China, J. Climate, 28, 3472-3495, doi:10.1175/Jcli-D-1400365.1, 2015.

Jokinen, T., Berndt, T., Makkonen, R., Kerminen, V. M., Junninen, H., Paasonen, P., Stratmann, F., Herrmann, H., Guenther, A. B., Worsnop, D. R., Kulmala, M., Ehn, M., and Sipila, M.: Production of extremely low volatile organic compounds from biogenic emissions: Measured yields and atmospheric implications, Proc. Nat. Acad. Sci. USA, 112, 7123 7128, doi:10.1073/pnas.1423977112, 2015. 
Kerminen, V. M. and Wexler, A. S.: The occurrence of sulfuric acidwater nucleation in plumes: Urban environment, Tellus B, 48, 65-82, doi:10.1034/j.1600-0889.1996.00007.x, 1996.

Kerminen, V.-M., Paramonov, M., Anttila, T., Riipinen, I., Fountoukis, C., Korhonen, H., Asmi, E., Laakso, L., Lihavainen, H., Swietlicki, E., Svenningsson, B., Asmi, A., Pandis, S. N., Kulmala, M., and Petäjä, T.: Cloud condensation nuclei production associated with atmospheric nucleation: a synthesis based on existing literature and new results, Atmos. Chem. Phys., 12, 1203712059, doi:10.5194/acp-12-12037-2012, 2012.

Korhonen, P., Kulmala, M., Laaksonen, A., Viisanen, Y., McGraw, R., and Seinfeld, J. H.: Ternary nucleation of $\mathrm{H}_{2} \mathrm{SO}_{4}, \mathrm{NH}_{3}$, and $\mathrm{H}_{2} \mathrm{O}$ in the atmosphere, J. Geophys. Res. Atmos., 104, 2634926353, doi:10.1029/1999jd900784, 1999.

Kroll, J. H., Ng, N. L., Murphy, S. M., Varutbangkul, V., Flagan, R. C., and Seinfeld, J. H.: Chamber studies of secondary organic aerosol growth by reactive uptake of simple carbonyl compounds, J. Geophys. Res. Atmos., 110, D23207, doi:10.1029/2005jd006004, 2005.

Kroll, J. H. and Seinfeld, J. H.: Chemistry of secondary organic aerosol: Formation and evolution of low-volatility organics in the atmosphere, Atmos. Environ., 42, 3593-3624, doi:10.1016/j.atmosenv.2008.01.003, 2008.

Kulmala, M. and Kerminen, V. M.: On the formation and growth of atmospheric nanoparticles, Atmos. Res., 90, 132-150, doi:10.1016/j.atmosres.2008.01.005, 2008.

Kulmala, M., Kerminen, V.-M., and Laaksonen, A.: Simulations on the effect of sulphuric acid formation on atmospheric aerosol concentrations, Atmos. Environ., 29, 377-382, 1995.

Kulmala, M., Dal Maso, M., Makela, J. M., Pirjola, L., Vakeva, M., Aalto, P., Miikkulainen, P., Hameri, K., and O’Dowd, C. D.: On the formation, growth and composition of nucleation mode particles, Tellus B, 53, 479-490, doi:10.1034/j.16000889.2001.530411.x, 2001.

Kulmala, M., Suni, T., Lehtinen, K. E. J., Dal Maso, M., Boy, M., Reissell, A., Rannik, Ü., Aalto, P., Keronen, P., Hakola, H., Bäck, J., Hoffmann, T., Vesala, T., and Hari, P.: A new feedback mechanism linking forests, aerosols, and climate, Atmos. Chem. Phys., 4, 557-562, doi:10.5194/acp-4-557-2004, 2004a.

Kulmala, M., Vehkamaki, H., Petaja, T., Dal Maso, M., Lauri, A., Kerminen, V. M., Birmili, W., and McMurry, P. H.: Formation and growth rates of ultrafine atmospheric particles: a review of observations, J. Aerosol. Sci., 35, 143-176, doi:10.1016/j.jaerosci.2003.10.003, 2004b.

Kulmala, M., Petaja, T., Nieminen, T., Sipila, M., Manninen, H. E., Lehtipalo, K., Dal Maso, M., Aalto, P. P., Junninen, H., Paasonen, P., Riipinen, I., Lehtinen, K. E. J., Laaksonen, A., and Kerminen, V. M.: Measurement of the nucleation of atmospheric aerosol particles, Nat. Protoc., 7, 1651-1667, doi:10.1038/nprot.2012.091, 2012.

Kurten, T., Lane, J. R., Jorgensen, S., and Kjaergaard, H. G.: A Computational Study of the Oxidation of $\mathrm{SO}_{2}$ to $\mathrm{SO}_{3}$ by GasPhase Organic Oxidants, J. Phys. Chem. A, 115, 8669-8681, doi:10.1021/Jp203907d, 2011.

Laaksonen, A., Kulmala, M., O’Dowd, C. D., Joutsensaari, J., Vaattovaara, P., Mikkonen, S., Lehtinen, K. E. J., Sogacheva, L., Dal Maso, M., Aalto, P., Petäjä, T., Sogachev, A., Yoon, Y. J., Lihavainen, H., Nilsson, D., Facchini, M. C., Cavalli, F., Fuzzi, S., Hoffmann, T., Arnold, F., Hanke, M., Sellegri, K., Umann, B.,
Junkermann, W., Coe, H., Allan, J. D., Alfarra, M. R., Worsnop, D. R., Riekkola, M.-L., Hyötyläinen, T., and Viisanen, Y.: The role of VOC oxidation products in continental new particle formation, Atmos. Chem. Phys., 8, 2657-2665, doi:10.5194/acp-82657-2008, 2008.

Li, M., Huang, X., Li, J., and Song, Y.: Estimation of biogenic volatile organic compound (BVOC) emissions from the terrestrial ecosystem in China using real-time remote sensing data, Atmos. Chem. Phys. Discuss., 12, 6551-6592, doi:10.5194/acpd12-6551-2012, 2012.

Lihavainen, H., Kerminen, V. M., Komppula, M., Hatakka, J., Aaltonen, V., Kulmala, M., and Viisanen, Y.: Production of "potential" cloud condensation nuclei associated with atmospheric newparticle formation in northern Finland, J. Geophys. Res. Atmos., 108, 4782, doi:10.1029/2003jd003887, 2003.

Lin, Y. L., Farley, R. D., and Orville, H. D.: Bulk Parameterization of the Snow Field in a Cloud Model, J. Clim. Appl. Meteorol., 22, 1065-1092, doi:10.1175/15200450(1983)022<1065:Bpotsf>2.0.Co;2, 1983.

Liu, S., Hu, M., Wu, Z. J., Wehner, B., Wiedensohler, A., and Cheng, Y. F.: Aerosol number size distribution and new particle formation at a rural/coastal site in Pearl River Delta (PRD) of China, Atmos. Environ., 42, 6275-6283, doi:10.1016/j.atmosenv.2008.01.063, 2008.

Liu, Y., Shao, M., Fu, L. L., Lu, S. H., Zeng, L. M., and Tang, D. G.: Source profiles of volatile organic compounds (VOCs) measured in China: Part I, Atmos. Environ., 42, 6247-6260, doi:10.1016/j.atmosenv.2008.01.070, 2008.

Lohmann, U. and Feichter, J.: Global indirect aerosol effects: a review, Atmos. Chem. Phys., 5, 715-737, doi:10.5194/acp-5-7152005, 2005.

Makkonen, R., Asmi, A., Kerminen, V.-M., Boy, M., Arneth, A., Hari, P., and Kulmala, M.: Air pollution control and decreasing new particle formation lead to strong climate warming, Atmos. Chem. Phys., 12, 1515-1524, doi:10.5194/acp-12-15152012, 2012.

Merikanto, J., Spracklen, D. V., Mann, G. W., Pickering, S. J., and Carslaw, K. S.: Impact of nucleation on global CCN, Atmos. Chem. Phys., 9, 8601-8616, doi:10.5194/acp-9-8601-2009, 2009.

Metzger, A., Verheggen, B., Dommen, J., Duplissy, J., Prevot, A. S. H., Weingartner, E., Riipinen, I., Kulmala, M., Spracklen, D. V., Carslaw, K. S., and Baltensperger, U.: Evidence for the role of organics in aerosol particle formation under atmospheric conditions, Proc. Natl. Acad. Sci. USA, 107, 6646-6651, doi:10.1073/pnas.0911330107, 2010.

Mlawer, E. J., Taubman, S. J., Brown, P. D., Iacono, M. J., and Clough, S. A.: Radiative transfer for inhomogeneous atmospheres: RRTM, a validated correlated-k model for the longwave, J. Geophys. Res. Atmos., 102, 16663-16682, doi:10.1029/97jd00237, 1997.

Myhre, G., Samset, B. H., Schulz, M., Balkanski, Y., Bauer, S., Berntsen, T. K., Bian, H., Bellouin, N., Chin, M., Diehl, T., Easter, R. C., Feichter, J., Ghan, S. J., Hauglustaine, D., Iversen, T., Kinne, S., Kirkevåg, A., Lamarque, J.-F., Lin, G., Liu, X., Lund, M. T., Luo, G., Ma, X., van Noije, T., Penner, J. E., Rasch, P. J., Ruiz, A., Seland, Ø., Skeie, R. B., Stier, P., Takemura, T., Tsigaridis, K., Wang, P., Wang, Z., Xu, L., Yu, H., Yu, F., Yoon, J.-H., Zhang, K., Zhang, H., and Zhou, C.: Radiative forcing of 
the direct aerosol effect from AeroCom Phase II simulations, Atmos. Chem. Phys., 13, 1853-1877, doi:10.5194/acp-13-18532013, 2013.

Nannoolal, Y., Rarey, J., and Ramjugernath, D.: Estimation of pure component properties - Part 3. Estimation of the vapor pressure of non-electrolyte organic compounds via group contributions and group interactions, Fluid Phase Equilib., 269, 117-133, doi:10.1016/j.fluid.2008.04.020, 2008.

O’Dowd, C. D., Jimenez, J. L., Bahreini, R., Flagan, R. C., Seinfeld, J. H., Hameri, K., Pirjola, L., Kulmala, M., Jennings, S. G., and Hoffmann, T.: Marine aerosol formation from biogenic iodine emissions, Nature, 417, 632-636, doi:10.1038/Nature00775, 2002.

Ortega, I. K., Suni, T., Boy, M., Gronholm, T., Manninen, H. E., Nieminen, T., Ehn, M., Junninen, H., Hakola, H., Hellen, H., Valmari, T., Arvela, H., Zegelin, S., Hughes, D., Kitchen, M., Cleugh, H., Worsnop, D. R., Kulmala, M., and Kerminen, V. M.: New insights into nocturnal nucleation, Atmos. Chem. Phys., 12, 4297-4312, 2012.

Paasonen, P., Sihto, S. L., Nieminen, T., Vuollekoski, H., Riipinen, I., Plass-Dulmer, C., Berresheim, H., Birmili, W., and Kulmala, M.: Connection between new particle formation and sulphuric acid at Hohenpeissenberg (Germany) including the influence of organic compounds, Boreal Environ. Res., 14, 616-629, 2009.

Paasonen, P., Nieminen, T., Asmi, E., Manninen, H. E., Petäj”a, T., Plass-Dülmer, C., Flentje, H., Birmili, W., Wiedensohler, A., Hõrrak, U., Metzger, A., Hamed, A., Laaksonen, A., Facchini, M. C., Kerminen, V.-M., and Kulmala, M.: On the roles of sulphuric acid and low-volatility organic vapours in the initial steps of atmospheric new particle formation, Atmos. Chem. Phys., 10, 11223-11242, doi:10.5194/acp-10-11223-2010, 2010.

Petäjä, T., Mauldin, III, R. L., Kosciuch, E., McGrath, J., Nieminen, T., Paasonen, P., Boy, M., Adamov, A., Kotiaho, T., and Kulmala, M.: Sulfuric acid and $\mathrm{OH}$ concentrations in a boreal forest site, Atmos. Chem. Phys., 9, 7435-7448, doi:10.5194/acp9-7435-2009, 2009.

Qi, X. M., Ding, A. J., Nie, W., Petäjä, T., Kerminen, V.-M., Herrmann, E., Xie, Y. N., Zheng, L. F., Manninen, H., Aalto, P., Sun, J. N., Xu, Z. N., Chi, X. G., Huang, X., Boy, M., Virkkula, A., Yang, X.-Q., Fu, C. B., and Kulmala, M.: Aerosol size distribution and new particle formation in the western Yangtze River Delta of China: 2 years of measurements at the SORPES station, Atmos. Chem. Phys., 15, 12445-12464, doi:10.5194/acp15-12445-2015, 2015.

Rattigan, O., Boniface, J., Swartz, E., Davidovits, P., Jayne, J., Kolb, C., and Worsnop, D.: Uptake of gas-phase $\mathrm{SO}_{2}$ in aqueous sulfuric acid: Oxidation by $\mathrm{H}_{2} \mathrm{O}_{2}, \mathrm{O}_{3}$, and $\mathrm{HONO}$, J. Geophys. Res. Atmos., 105, 29065-29078, 2000.

Schobesberger, S., Junninen, H., Bianchi, F., Lonn, G., Ehn, M., Lehtipalo, K., Dommen, J., Ehrhart, S., Ortega, I. K., Franchin, A., Nieminen, T., Riccobono, F., Hutterli, M., Duplissy, J., Almeida, J., Amorim, A., Breitenlechner, M., Downard, A. J., Dunne, E. M., Flagan, R. C., Kajos, M., Keskinen, H., Kirkby, J., Kupc, A., Kurten, A., Kurten, T., Laaksonen, A., Mathot, S., Onnela, A., Praplan, A. P., Rondo, L., Santos, F. D., Schallhart, S., Schnitzhofer, R., Sipila, M., Tome, A., Tsagkogeorgas, G., Vehkamaki, H., Wimmer, D., Baltensperger, U., Carslaw, K. S., Curtius, J., Hansel, A., Petaja, T., Kulmala, M., Donahue, N. M., and Worsnop, D. R.: Molecular understanding of atmo- spheric particle formation from sulfuric acid and large oxidized organic molecules, Proc. Natl. Acad. Sci. USA, 110, 17223 17228, doi:10.1073/pnas.1306973110, 2013.

Scott, C. E., Rap, A., Spracklen, D. V., Forster, P. M., Carslaw, K. S., Mann, G. W., Pringle, K. J., Kivekäs, N., Kulmala, M., Lihavainen, H., and Tunved, P.: The direct and indirect radiative effects of biogenic secondary organic aerosol, Atmos. Chem. Phys., 14, 447-470, doi:10.5194/acp-14-447-2014, 2014.

Sihto, S.-L., Kulmala, M., Kerminen, V.-M., Dal Maso, M., Petäjä, T., Riipinen, I., Korhonen, H., Arnold, F., Janson, R., Boy, M., Laaksonen, A., and Lehtinen, K. E. J.: Atmospheric sulphuric acid and aerosol formation: implications from atmospheric measurements for nucleation and early growth mechanisms, Atmos. Chem. Phys., 6, 4079-4091, doi:10.5194/acp-6-4079-2006, 2006.

Sipila, M., Berndt, T., Petaja, T., Brus, D., Vanhanen, J., Stratmann, F., Patokoski, J., Mauldin, R. L., Hyvarinen, A. P., Lihavainen, H., and Kulmala, M.: The Role of Sulfuric Acid in Atmospheric Nucleation, Science, 327, 1243-1246, doi:10.1126/science.1180315, 2010.

Tie, X., Geng, F., Guenther, A., Cao, J., Greenberg, J., Zhang, R., Apel, E., Li, G., Weinheimer, A., Chen, J., and Cai, C.: Megacity impacts on regional ozone formation: observations and WRFChem modeling for the MIRAGE-Shanghai field campaign, Atmos. Chem. Phys., 13, 5655-5669, doi:10.5194/acp-13-56552013, 2013.

Volkamer, R., Jimenez, J. L., San Martini, F., Dzepina, K., Zhang, Q., Salcedo, D., Molina, L. T., Worsnop, D. R., and Molina, M. J.: Secondary organic aerosol formation from anthropogenic air pollution: Rapid and higher than expected, Geophys. Res. Lett., 33, L17811, doi:10.1029/2006g1026899, 2006.

Wang, H. L., Zhu, B., Shen, L. J., An, J. L., Yin, Y., and Kang, H. Q.: Number size distribution of aerosols at Mt. Huang and Nanjing in the Yangtze River Delta, China: Effects of air masses and characteristics of new particle formation, Atmos. Res., 150, 42-56, doi:10.1016/j.atmosres.2014.07.020, 2014.

Wang, M. and Penner, J. E.: Aerosol indirect forcing in a global model with particle nucleation, Atmos. Chem. Phys., 9, 239-260, doi:10.5194/acp-9-239-2009, 2009.

Wang, Z. B., Hu, M., Wu, Z. J., Yue, D. L., Zheng, J., Zhang, R. Y., Pei, X. Y., Paasonen, P., Dal Maso, M., Boy, M., and Wiedensohler, A.: Investigation of the connections between atmospheric new particle formation and organics at an urban site of Beijing, Atmos. Chem. Phys. Discuss., 13, 3419-3450, doi:10.5194/acpd-13-3419-2013, 2013a.

Wang, Z. B., Hu, M., Mogensen, D., Yue, D. L., Zheng, J., Zhang, R. Y., Liu, Y., Yuan, B., Li, X., Shao, M., Zhou, L., Wu, Z. J., Wiedensohler, A., and Boy, M.: The simulations of sulfuric acid concentration and new particle formation in an urban atmosphere in China, Atmos. Chem. Phys., 13, 11157-11167, doi:10.5194/acp-13-11157-2013, 2013 b.

Weber, R. J., McMurry, P. H., Mauldin, R. L., Tanner, D. J., Eisele, F. L., Clarke, A. D., and Kapustin, V. N.: New particle formation in the remote troposphere: A comparison of observations at various sites, Geophys. Res. Lett., 26, 307-310, doi:10.1029/1998g1900308, 1999.

Wei, W., Wang, S. X., Chatani, S., Klimont, Z., Cofala, J., and Hao, J. M.: Emission and speciation of non-methane volatile organic 
compounds from anthropogenic sources in China, Atmos. Environ., 42, 4976-4988, doi:10.1016/j.atmosenv.2008.02.044, 2008.

Xiao, S., Wang, M. Y., Yao, L., Kulmala, M., Zhou, B., Yang, X., Chen, J. M., Wang, D. F., Fu, Q. Y., Worsnop, D. R., and Wang, L.: Strong atmospheric new particle formation in winter in urban Shanghai, China, Atmos. Chem. Phys., 15, 1769-1781, doi:10.5194/acp-15-1769-2015, 2015.

Yli-Juuti, T., Nieminen, T., Hirsikko, A., Aalto, P. P., Asmi, E., Hõrrak, U., Manninen, H. E., Patokoski, J., Dal Maso, M., Petäjä, T., Rinne, J., Kulmala, M., and Riipinen, I.: Growth rates of nucleation mode particles in Hyytiälä during 20032009: variation with particle size, season, data analysis method and ambient conditions, Atmos. Chem. Phys., 11, 12865-12886, doi:10.5194/acp-11-12865-2011, 2011.

Yu, F. and Luo, G.: Simulation of particle size distribution with a global aerosol model: contribution of nucleation to aerosol and CCN number concentrations, Atmos. Chem. Phys., 9, 76917710, doi:10.5194/acp-9-7691-2009, 2009.

Yue, D. L., Hu, M., Zhang, R. Y., Wang, Z. B., Zheng, J., Wu, Z. J., Wiedensohler, A., He, L. Y., Huang, X. F., and Zhu, T.: The roles of sulfuric acid in new particle formation and growth in the mega-city of Beijing, Atmos. Chem. Phys., 10, 4953-4960, doi:10.5194/acp-10-4953-2010, 2010.

Zhang, Q., Stanier, C. O., Canagaratna, M. R., Jayne, J. T., Worsnop, D. R., Pandis, S. N., and Jimenez, J. L.: Insights into the chemistry of new particle formation and growth events in Pittsburgh based on aerosol mass spectrometry, Environ. Sci. Technol., 38, 4797-4809, doi:10.1021/Es035417u, 2004.
Zhang, R. Y., Suh, I., Zhao, J., Zhang, D., Fortner, E. C., Tie, X. X., Molina, L. T., and Molina, M. J.: Atmospheric new particle formation enhanced by organic acids, Science, 304, 1487-1490, doi:10.1126/science.1095139, 2004.

Zheng, J. Y., Zhang, L. J., Che, W. W., Zheng, Z. Y., and Yin, S. S.: A highly resolved temporal and spatial air pollutant emission inventory for the Pearl River Delta region, China and its uncertainty assessment, Atmos. Environ., 43, 5112-5122, doi:10.1016/j.atmosenv.2009.04.060, 2009.

Zhou, L., Gierens, R., Sogachev, A., Mogensen, D., Ortega, J., Smith, J. N., Harley, P. C., Prenni, A. J., Levin, E. J. T., Turnipseed, A., Rusanen, A., Smolander, S., Guenther, A. B., Kulmala, M., Karl, T., and Boy, M.: Contribution from biogenic organic compounds to particle growth during the 2010 BEACHON-ROCS campaign in a Colorado temperate needleleaf forest, Atmos. Chem. Phys., 15, 8643-8656, doi:10.5194/acp15-8643-2015, 2015.

Zhou, L. X., Nieminen, T., Mogensen, D., Smolander, S., Rusanen, A., Kulmala, M., and Boy, M.: SOSAA - a new model to simulate the concentrations of organic vapours, sulphuric acid and aerosols inside the ABL - Part 2: Aerosol dynamics and one case study at a boreal forest site, Boreal Environ. Res., 19, 237-256, 2014. 